Int. J. Dev. Biol. 61: 665-681 (2017)

doi: $10.1387 / \mathrm{ijdb} .170230 \mathrm{zk}$

\title{
Amphioxus photoreceptors - insights into the evolution of vertebrate opsins, vision and circadian rhythmicity
}

\author{
JIRI PERGNER and ZBYNEK KOZMIK* \\ Laboratory of Transcriptional Regulation, Institute of Molecular Genetics of the Czech Academy of Sciences, Prague, \\ Czech Republic,
}

\begin{abstract}
Studies on amphioxus, representing the most basal group of chordates, can give insights into the evolution of vertebrate traits. The present review of amphioxus research is focused on the physiology of light-guided behavior as well as on the fine structure, molecular biology, and electrophysiology of the nervous system, with special attention being given to the photoreceptive organs. The amphioxus visual system is especially interesting because four types of receptors are involved in light detection - dorsal ocelli and Joseph cells (both rhabdomeric photoreceptors) and the frontal eye and lamellar body (both ciliary photoreceptors). Here, we consider how the available information on photoreceptive organs and light-guided behavior in amphioxus helps generate hypotheses about the history of these features during chordate and subsequently vertebrate evolution.
\end{abstract}

KEY WORDS: chordate, opsin evolution, photoreceptor, eye evolution, phototransduction

\section{Introduction}

Light is a crucial environmental signal for most of the organisms on earth. Light sensing systems have evolved to be uniquely suited to the environment and behavior of any given species. Light cues are necessary for mediating biological processes such as circadian rhythms, reproductive cycles and most importantly visually guided behavior. Animals detect light using sensory cells known as photoreceptors, present in the eyes or, in the case of extraocular photoreceptors, outside of the eyes. Although other systems of light detection exist in the animal kingdom, such as cryptochromes (Rivera et al., 2012) or LITE-1 (Gong et al., 2016), opsins, the seven-pass transmembrane proteins that belong to the G-Protein Coupled Receptor (GPCR) superfamily, are dominantly utilized as visual pigments among Metazoa (Feuda et al., 2014). A simple eye can be defined as a photoreceptor cell neighboring a shielding pigment cell, or, in extreme cases, both photoreceptive and pigment function can be combined together in one cell. At the other end of the sophistication spectrum, complex eyes with advanced optics can be found in various animals. For example the vertebrate-style camera eye is one of the most elaborate types of animal eye. The huge diversity, as well as the extreme complexity, of eyes in different animals was already puzzling scientists in Darwin's time (Darwin, 1859).

Recent studies have shown that cephalochordates may serve as a valuable model providing useful insight into photoreception in ancestral chordates as well as into evolution of the vertebrate eye. Cephalochordates (common name amphioxus or lancelets) represent the most basal branch of chordates (which also includes vertebrates), live worldwide in sandy shallow seashores and can be divided into three genera, Asymmetron, Branchiostoma, and Epigonichthys (Bertrand and Escriva, 2011).

The amphioxus body plan resembles the body plan of most extant as well as extinct chordates, having a dorsally located notochord and neural tube, a ventral gut, a perforated pharynx with gill slits, segmented muscles and gonads and a tail fin. The amphioxus central nervous system comprises a dorsal neural tube running through the whole length of the body. The anterior part of the neural tube is slightly expanded, forming a so-called cerebral

\footnotetext{
Abbreviations used in this paper: 2RWGD, two rounds of whole genome duplication; cAMP, cyclic adenosine monophosphate; cGMP, cyclic guanosine monophosphate; CNG channel, cyclic nucleotide gated channel; CV, cerebral vesicle; DAG, diacylglycerol; DO, dorsal ocellus; EM, electron microscopical; FE, frontal eye; GNA guanine nucleotide-binding protein alpha subunit; GPCR, G protein coupled receptor; IP3, inositol trisphosphate; ipRGG, intrinsic photosensitive ganglion cell;JC, Joseph cell; LB, lamellar body; PDE, phosphodiesterase; PIP2, phosphatidylinositol 4,5-bisphosphate; PKC, protein kinase C; PLC, phospholipase $\mathrm{C}$; PMC, primary motor center; PUFA, polyunsaturated fatty acid; RDGN, retinal determination gene network; RPE, retinal pigmented epithelium.
}

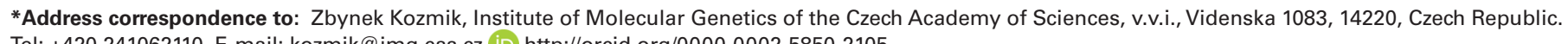
Tel: +420 241062110. E-mail: kozmik@img.cas.cz (iD) http://orcid.org/0000-0002-5850-2105

Submitted: 9 September, 2017; Accepted: 22 September, 2017.

ISSN: Online 1696-3547, Print 0214-6282

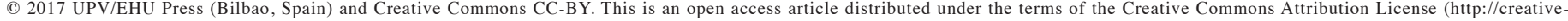

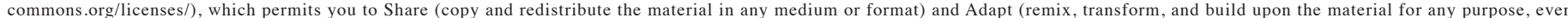

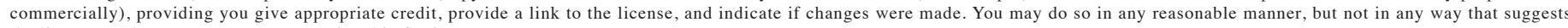
the licensor endorses you or your use. Printed in Spain 
vesicle (CV). Based on morphological and molecular analysis, the cerebral vesicle is considered to be a homolog of the vertebrate diencephalon or di- plus mesencephalon with indistinguishable borders (Albuixech-Crespo et al., 2017; Holland, 2017).

Amphioxus possesses four distinct photoreceptive organs - the frontal eye (FE), lamellar body (LB), Joseph cells (JCs) and dorsal ocelli (DO) (Fig. 1). Amphioxus development, from fertilization to metamorphosis, takes about several weeks to several months depending on species. Amphioxus larvae are planktonic, while after metamorphosis, adult amphioxus spend most of their life burrowed in the sand with just the anterior part of the body projecting outside, in order to allow feeding by filtering food particles. Associated with such a dramatic changes in the way of life are also changes in response to light stimuli.

\section{Amphioxus responses to light stimuli}

The rapid reactions of amphioxus to light had been discovered by Costa (1834), and thorough study of amphioxus sensory reactions was performed at the beginning of the $20^{\text {th }}$ century. Parker (1908) described sensory reactions of amphioxus to various physical and chemical stimuli, including light. Parker's observation about amphioxus photoresponses were in agreement with previous studies (Hesse, 1898; Willey, 1894), showing negative phototactic

A

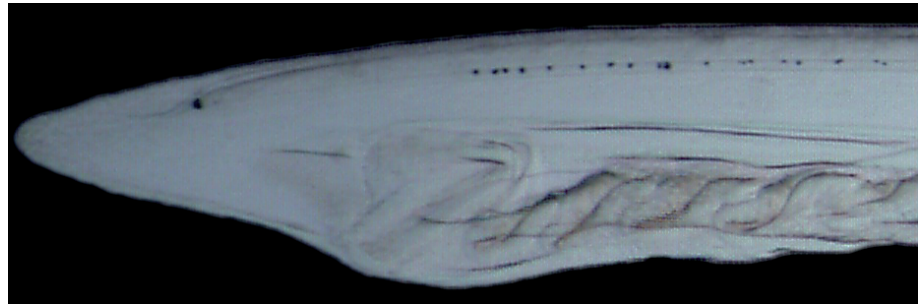

B

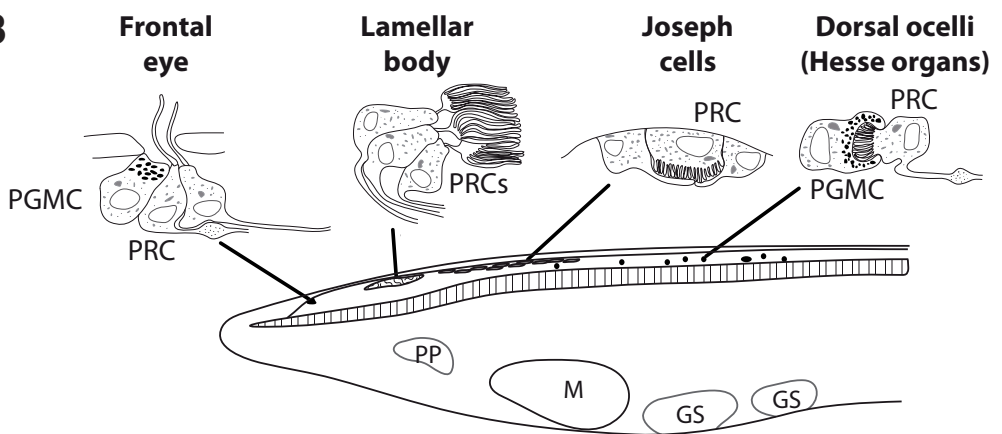

C

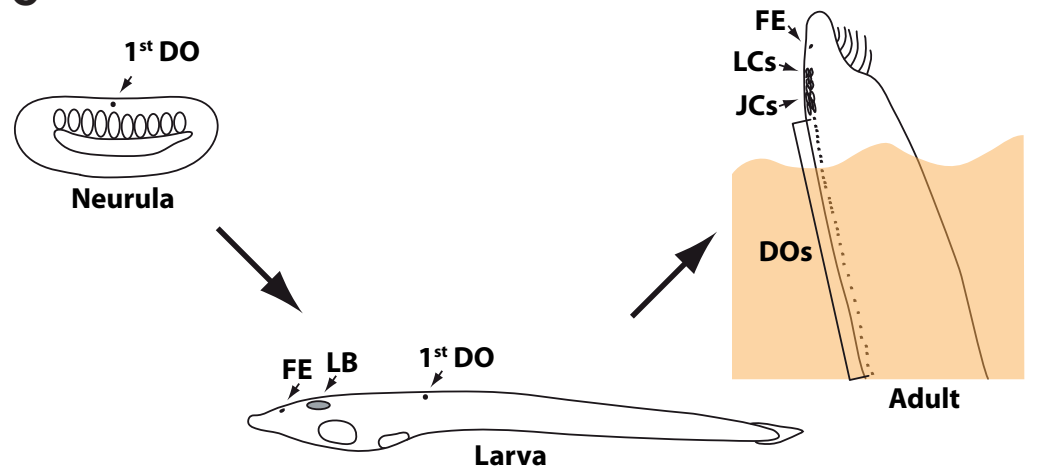

responses in adult amphioxus (Parker, 1908). Moreover, it was shown that amphioxus adults evince higher burrowing activity during the night (Schomerus et al., 2008). Several later studies added more information about larval amphioxus reactions to light. Chin (1941) documented collections of planktonic larvae of Branchiostoma belcheri in different times of the day and night. During the day, amphioxus larvae were found close to the bottom, while with decrease in light intensity during sunset, most larvae were found close to the surface. Comparable observations were made two decades later by Wickstead and Bone (1959), who found an increase in concentration of amphioxus larvae close to the surface shortly before and after sunset for $B$. belcheri as well as Branchiostoma lanceolatum. Various amphioxus species thus demonstrate typical diurnal migration. Additionally, Webb (1969) showed that amphioxus larvae actively swim to the surface and passively sank down, with mouth open, catching food. This behavior is also light dependent. Moreover, it was shown that the FE might be important for larval light guided behavior. During feeding, amphioxus larvae adopt a vertical posture in the water column in such a way that the FE pigment cells screen off most of light coming towards the FE photoreceptor cells (Stokes and Holland, 1995). Larvae are able to change their orientation in the order of minutes, when the light direction is changed. Such an orientation to incoming light might be important for minimizing the overhead illumination and improving the ability to discriminate between levels of light intensity (Lacalli, 1996). Amphioxus reacts to light as early as the neurula stage. For Branchiostoma floridae it was shown that, when kept in Petri dishes, neurulae swim up to the surface of the water in the direction towards the highest light intensity (Holland and Yu, 2004). No such behavior occurs in the same developmental stage in B. lanceolatum (our observations) or representative of another amphioxus genus Asymmetron lucayanum (Holland and Holland, 2010). Whether light attraction in $B$. floridae neurula is connected with ongoing development of the first dorsal ocellus is unclear. Why this phototactic behavior of neurulae was not observed in other amphioxus species remains a mystery.

Of special interest is the dependence of amphioxus spawning on light conditions. Branchiostoma species kept in laboratory conditions (B. floridae, $B$. lanceolatum and $B$. belcheri) spawn within 1 hour after switching off the light (1h after simulated sunset) (Fuentes et al., 2007; Holland and Yu, 2004; Li et al., 2013). Spawning of Branchiostoma shortly after sunset likely occurs in nature as well. The same light dependency for spawning is also found for A. lucayanum. Moreover most individuals of $A$. lucayanum usually spawn one day before the new moon (Holland,

Fig. 1. Overview of amphioxus photoreceptive organs. (A) Detail of anterior part of 3 weeks old larvae of Branchiostoma floridae; (B) Scheme of particular photoreceptive organs developed in larvae presented in (A). Important morphological landmarks of developing amphioxus larvae are shown (adapted after Lacalli (2004)). PRC, photoreceptor cell; PGMC, pigment cell; PP, preoral pit; $M$, mouth; GS, gill slit. (C) Simplified scheme of picked developmental stages of amphioxus (mid-neurula; early larva; adult - shown in typical vertical position in the sand burrow). The presence of individual photoreceptive organs is stressed. FE, frontal eye; LB, lamellarbody; LC, lamellate cell; JC, Joseph cell; DO/DOs, dorsal ocellus/ocelli. 
2011) proving another piece of evidence for the key role of light for animal behavior.

Taken together, amphioxus manifests various light dependent behavioral responses. These include positive phototaxis in early developmental stages, vertical diurnal migration in larval stages, and negative phototaxis in benthic adult stage with light dependent spawning cycles (summarized in Table 1). The observed behavior is in concordance with the behavior of many marine organisms, including vertebrates.

\section{Opsins as key molecular determinants of light detection in amphioxus}

For light detection, animals use opsins and/or cryptochromes. Opsins are utilized as visual pigments in all Eumetazoa (Porter et al., 2012), while cryptochromes function as a photosensitive pigment in sponges (Muller et al., 2013; Rivera et al., 2012). In vertebrates, the role of cryptochromes as functional pigments has not been proven to date, but their role in circadian rhythmicity is highly probable (Kume et al., 1999; Kutta et al., 2017; Shearman et al., 2000). Although three cryptochrome genes have been identified in the B. floridae genome (Haug et al., 2015), their expression was not determined and their function remains elusive. For now it thus seems likely that opsins are more important than cryptochromes for photoreception in amphioxus, a situation analogous to that in vertebrates (Haug et al., 2015; van der Schalie and Green, 2005).

The opsins are members of a large family of $G$ protein coupled receptors (GPCRs). An opsin consist of a protein moiety and a non-protein chromophore, usually 11 -cis retinal, less often all-trans retinal (a photoproduct of 11-cis-retinal) (Terakita, 2005). The opsins can be distinguished from other GPCRs by the presence of a highly conserved lysine residue K296 (amino acid position 296 in bovine rhodopsin), that serves for covalent binding of retinal. Based on their primary structure, opsins are usually divided to four main groups: 1. c-opsins present in ciliary photoreceptors (typical visual photoreceptors in vertebrates); 2 . r-opsins present in rhabdomeric photoreceptors (typical visual photoreceptors in protostome invertebrates); 3. Cnidopsins, a group consisting exclusively of Cnidarian opsins and 4. group of nonvisual opsins, called Group4 (Liegertova et al., 2015; Porter et al., 2012). Recently opsins were divided into up to ten groups (Ramirez et al.,
2016) - nine subgroups originating from subtle division of the c-, r- and Group4 opsins, plus a group of Cnidopsins.

Aquatic animals usually display higher variability than terrestrial animals in their opsin gene repertoire (Biscontin et al., 2016; Liegertova et al., 2015; Ramirez et al., 2016) and amphioxus is no exception to this rule. Approximately twenty functional opsin genes have been identified in each of the amphioxus genomes completed so far: 21 opsin genes in B. floridae, 21 opsin genes plus one opsin pseudogene in B. lanceolatum and 20 opsin genes in B. belcheri (Holland et al., 2008; Pantzartzi et al., 2017). Transcripts of all of the identified $B$. lanceolatum opsins were detected in various developmental stages and/or in tissues of adult specimens (Pantzartzi et al., 2017). Representatives of all major opsin groups (except the Cnidopsin group) can be found in the genomes of $B$. floridae, $B$. lanceolatum and $B$. belcheri. More specifically, the recently assembled genome of $B$. lanceolatum contains five amphioxus opsins that cluster with c-opsins; nine amphioxus opsins clustering with Group4 and seven amphioxus opsins clustering with r-opsins (Fig. 2A). Of the five amphioxus c-type opsins, none clusters in phylogenetic tree within the group of the vertebrate visual and non-visual c-opsins (Pantzartzi et al., 2017). This is in agreement with the proposed evolution of genes involved in vertebrate phototransduction cascade after two rounds of whole genome duplication (2RWGD) that occurred after the split of amphioxus lineage and lineage leading to vertebrates (Lamb and Hunt, 2017; Lamb et al., 2016; Larhammar et al., 2009). Group4 amphioxus opsins representing neuropsins and putative Go-coupled opsins (a group of opsins signaling through the $\mathrm{G} \alpha \mathrm{O}$ subunit of trimeric $G$ proteins) are of special interest. Several gains and losses of amphioxus opsin genes in this subgroup, even between closely related species $B$. floridae and $B$. lanceolatum, have recently been identified. This indicates possible specific adjustment of the Go opsin repertoire in connection with different light conditions in habitats of particular Branchiostoma species. All amphioxus genomes examined so far contain a single melanopsin gene, an orthologue of the r-type opsin (melanopsin) expressed in vertebrates in intrinsically photosensitive Retinal Ganglion Cells (ipRGCs) (Provencio et al., 1998). The rest of the putative r-type amphioxus opsins (six opsins) cluster together to form a specific so called "Amphiop6" group (Koyanagi et al., 2002) that has not been found outside the Branchiostoma genus.

TABLE 1

\section{OVERVIEW OF REACTIONS TO LIGHT STIMULI DURING INDIVIDUAL AMPHIOXUS DEVELOPMENTAL STAGES}

\begin{tabular}{|c|c|c|c|}
\hline Developmental stage & Species & Response to light & References \\
\hline Neurula & $\begin{array}{l}\text { B. floridae } \\
\text { B. lanceolatum } \\
\text { A. lucayanum }\end{array}$ & $\begin{array}{l}\text { Accumulation at surface level facing to the direction of the light source } \\
\text { No response } \\
\text { No response }\end{array}$ & $\begin{array}{l}\text { Holland and Yu, } 2004 \\
\text { This study } \\
\text { Holland and Holland, } 2010\end{array}$ \\
\hline Larva & $\begin{array}{l}\text { B. floridae } \\
\text { B. belcheri } \\
\text { B. lanceolatum }\end{array}$ & $\begin{array}{l}\text { During hovering in water column orientation with FE facing from the light source } \\
\text { Diurnal migration - close to the bottom during day, close to the surface level during and after sunset } \\
\text { Diurnal migration - close to the bottom during day, close to the surface level during and after sunset } \\
\text { Swimming to surface and then catching the food sanking down with mouth open }\end{array}$ & $\begin{array}{l}\text { Stokes and Holland, } 1995 \\
\text { Chin, } 1941 \text {; Wickstead and Bone, } 1959 \\
\text { Wickstead and Bone, } 1959 \\
\text { Webb, } 1969\end{array}$ \\
\hline \multirow[t]{2}{*}{ Adult } & B. lanceolatum & $\begin{array}{l}\text { Negative phototaxis } \\
\text { Increased locomotor activity in the burrow during the night (suppressed by light) }\end{array}$ & $\begin{array}{l}\text { Costa, 1834; Willey, } 1894 ; \text { Hesse, } 1898 \\
\text { Schomerus et al., } 2008\end{array}$ \\
\hline & B. caribbaeum & Negative phototaxis & Parker, 1908 \\
\hline \multirow[t]{2}{*}{$\begin{array}{l}\text { Adult - } \\
\text { spawning behavior }\end{array}$} & $\begin{array}{l}\text { B. floridae } \\
\text { B. lanceolatum } \\
\text { B. belcheri } \\
\text { A. lucayanum }\end{array}$ & $\begin{array}{l}\text { Spawning } 1 \mathrm{~h} \text { after sunset }{ }^{\mathrm{a}} \\
\text { Spawning } 1 \mathrm{~h} \text { after sunset }{ }^{\mathrm{a}} \\
\text { Spawning } 1 \mathrm{~h} \text { after sunset } \\
\text { Spawning } 1 \mathrm{~h} \text { after sunset }\end{array}$ & $\begin{array}{l}\text { Holland and Yu, } 2004 \\
\text { Fuentes et al., } 2007 \\
\text { Li et al., } 2013 \\
\text { Holland, } 2011\end{array}$ \\
\hline & A. lucayanum & Spawning one day before the new moon ${ }^{\mathrm{b}}$ & Holland, 2011 \\
\hline
\end{tabular}


Due to the key phylogenetic position of amphioxus, their opsins provide a unique model for understanding vertebrate opsin evolution and mechanisms of opsin signaling. Since retinal has its peak absorption in UV region of the spectrum, tuning of opsin structure is necessary, to shift the absorption maximum into the visible range. To achieve this and to stabilize the Schiff base linkage between retinal and K296, the presence of a negatively charged amino acid (usually glutamate), the so-called counterion, is important. In most vertebrate opsins E113 (glutamate at position 113) serves as the counterion, while in other opsins it is usually E181 (Terakita et al., 2004). It thus appears that E181 was the ancestral counterion position, and that evolution of new features of vertebrate opsins was connected with the switch to counterion position E113. Terakita et al., (2004) studied the counterion in two B. belcheri Group4 opsins (Op12a and Op14), both having their counterion at position 181 and not 113. It was shown that switch of counterion from position E181 to E113 enhanced efficiency of $G$ protein activation by vertebrate opsin and was also a key step for emergence of red-sensitive opsins in vertebrates (Terakita et al., 2004) (Fig. 2B). From all examined B. lanceolatum opsins, only two (Op19 and Op20) have glutamate (E) at position 113, while one (Op11) has a different negative amino acid aspartate (D) at that position (for details see Pantzartzi et al., (2017)). Whether D/ E113 in any of these amphioxus opsins serves as a counterion still needs to be determined. Another important feature in opsin structure is the so-called tripeptide - a triptych of amino acids in the C-terminal part of opsin protein, responsible for contact between opsin and trimeric G protein (Marin et al., 2000; Plachetzki et al., 2007). Amphioxus opsins show a highly variable tripeptide sequence including the well-known tripeptide NKQ found in c-type opsin Op4 (a tripeptide typical of vertebrate visual opsins) and characteristic rhabdomeric-type HPK tripeptide identified in melanopsin (Op15) (for more details see Pantzartzi et al., (2017)). It was shown that amphioxus Op12a can bind 11-cis-retinal as well as all-trans-retinal (Tsukamoto et al., 2005). Vertebrate opsins have negligible affinity for all-trans-retinal. In vertebrate opsins, after light mediated conversion of 11-cis-retinal to all-trans-retinal, the all-trans-retinal is released, and replaced with 11-cis-retinal. The decrease in affinity
A

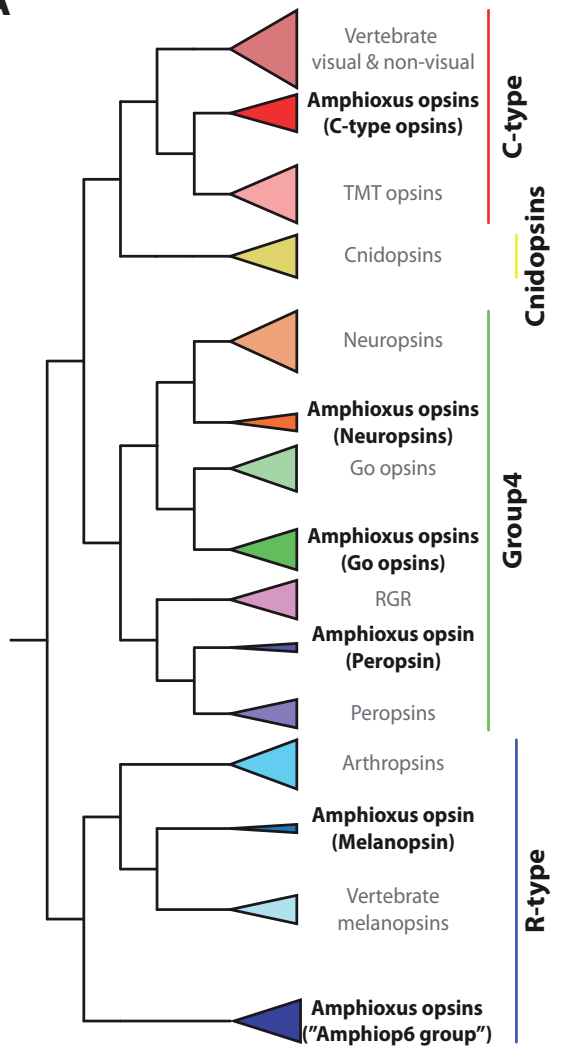

B

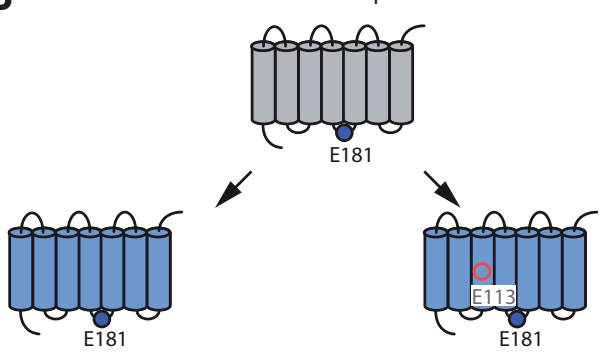

Opsins diversification ancestral state retained in invertebrate Gq and Go opsins (including amphioxus)

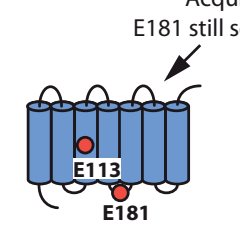

Synergistically acting counterions E113 \& E181 in Ciona opsin Ci-opsin1
Acquisition of E113,

still serves as counterion

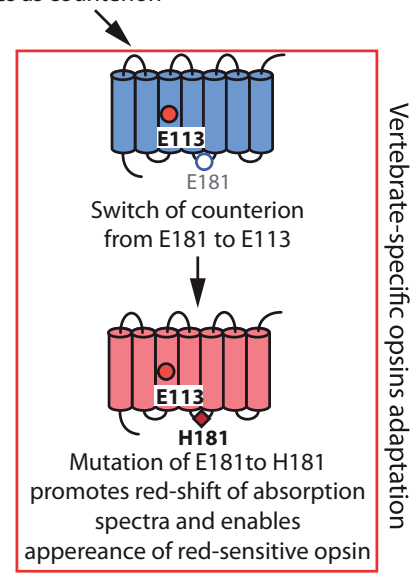

Fig. 2. The opsins in amphioxus - phylogenetic tree and evolution. (A) Simplified phylogenetic tree of opsins, with stressed position of amphioxus opsins. Except for Cnidopsins, representantatives of each opsin family can be found in the amphioxus genome. Notable is expansion of several opsin families in amphioxus, namely Group4 opsins and R-type opsins. For detailed phylogenetic tree see Pantzartzi et al., (2017). (B) Scheme of proposed evolution of vertebrate specific opsin characteristics (mainly counterion). In ancestral opsin glutamate (E) at position 181 served as counterion. This counterion was retained in opsins of many invertebrate species, including amphioxus. During evolution, opsin of common ancestor of urochordates and vertebrates (commonly called "olfactores") attained glutamate at position 113. Due to subsequent changes in opsin structure, E113 became new counterion. In urochordate opsin both E113 and E181 act as synergistical counterions. In vertebrates function of E181 as counterion was lost and E113 retained as the only counterion present. Lower constraints on aminoacid present in position 181 led in vertebrates to acquisition of histidine (H) at this position and enabled a switch of opsin absorbance to red-spectrum. Scheme adapted from Terakita et al., (2012). Ciona opsin data based on Kojima et al., (2017). 
for all-trans-retinal enabled complete reduction of dark noise as well as faster exchange of all-trans-retinal for 11 -cis-retinal during recovery period of vertebrate opsins. Rearrangements in opsin primary structure during evolution were therefore connected with enhanced affinity of vertebrate visual opsin for 11-cis-retinal and decreased affinity for all-trans-retinal. Additionally, amphioxus opsins have been shown to be less efficient in activating the downstream signaling cascade compared with vertebrate opsins (Terakita et al., 2004). Vertebrate opsins thus underwent additional improvement to achieve higher activating potential, and consequently gained better signal yield per captured photon, when compared with ancestral opsins.

Several genomic and biochemical studies of amphioxus opsins confirm that amphioxus is the best proxy to gain insight into evolution of vertebrate opsins and their specific properties. With a complete list of amphioxus opsin genes published recently (Pantzartzi et al., 2017), it will be worthwhile performing further biochemical studies (mainly to resolve the position of possible counterions and the nature of the tripeptides) to broaden knowledge about vertebrate opsin evolution.

\section{Amphioxus photoreceptive organs}

Four different photoreceptive organs, namely the frontal eye (FE), lamellar body (LB), Joseph cells (JCs) and dorsal ocelli (DO), respectively, have been described in amphioxus. Two of them, the FE and LB, consist of photoreceptor cells with ciliary morphology. Ciliary photoreceptors expand their membrane by modifying a non-motile cilium (with typical 9+0 microtubule structure) (Satir and Christensen, 2008), enabling incorporation of more molecules of photopigment in membrane and thus leading to higher efficiency for capturing photons. Ciliary photoreceptors serve as visual photoreceptors in vertebrates (Lamb, 2013; Lamb et al., 2007) and as non-visual photoreceptors in invertebrates (Arendt et al., 2004) (ciliary photoreceptors were, however, found also in eyes of some invertebrates, e.g. jellyfish or fan worms (Eakin and Westfall, 1962b; Lawrence and Krasne, 1965)). On the other hand, JCs and $\mathrm{DO}$ are formed of rhabdomeric photoreceptors (the typical visual photoreceptors in most protostomes) that utilize surface microvilli to attain expanded cell membrane. The presence of pigment cells makes the FE and DO directional photoreceptors. In contrast, the LB and JCs, lacking adjacent pigment, are non-directional photoreceptors. The homology between amphioxus photoreceptive organs and their possible vertebrate counterparts was enigmatic for a long time. In the subsequent sections we aim to summarize all relevant data regarding each of the photoreceptive organs in amphioxus. In addition, we present a current view about possible homologies between amphioxus and vertebrate photoreceptive organs.

\section{Frontal eye}

Due to its location at the anterior tip of the CV and the presence of pigment cells, the FE was already considered as a photoreceptive organ homologous to the vertebrate lateral eye by scientists in the $19^{\text {th }}$ century (Joseph, 1904; Kemna, 1904; Kohl, 1890). Early studies dealing with photoreception of amphioxus, nevertheless, pushed the FE to the sidelines, showing, that the DO are more important for adult amphioxus light-guided behavior (Hesse, 1898; Parker, 1908). Parker (1908) (and later more precisely Crozier
(1917)) confirmed an observation made by Hesse (1898), that the adult amphioxus photoresponse is connected with the presence of DO and he rejected the proposal of Krause (1888) that amphioxus can sense light with the whole neural tube. Parker also repeated experiments done by Nagel and Hesse, showing that upon removal of the anterior body end with the frontal eye, the rest of the body of the amphioxus still responded to the light in the same way as in intact animals (Hesse, 1898; Nagel, 1896). This cast doubt on the role of the FE in amphioxus photoresponses. Moreover no trace of optic nerve projecting from the FE posteriorly to the CV was observed at that time, which also questioned FE functionality as a possible photoreceptive organ. Yet Parker (1908) showed that when adult amphioxus was transversely cut in two parts, the anterior half was able to react to light, while the posterior half lost its light sensitivity, retaining its ability to be stimulated with addition of weak acid to the water. His results thus showed, that the anterior part of the neural tube (and probably also the FE) must be necessary for processing the photo-response, and that there is probably no direct connection between the dorsal ocelli and motor neurons. Although connections between the dorsal ocelli and the FE to motoneurons in adult amphioxus are still unknown, observations in $B$. floridae larvae show, contrary to Parker's proposal, direct connection between $1^{\text {st }}$ dorsal ocellus and motoneurons (Lacalli, 2002). Later, it was postulated that FE plays some role in regulation of the startle response after light illumination in adult amphioxus (Guthrie, 1975). Animals with the CV removed reacted more strongly to sudden illumination, and their reactions were more stereotyped and reliable compared to untreated animals (Guthrie, 1975). Additionally, as mentioned earlier, the importance of the frontal eye for larval vertical orientation, possibly necessary for feeding, has been documented (Stokes and Holland, 1995).

Electron microscopical (EM) examination of the CV in adult amphioxus showed that cells in the anterior tip of that region are arranged in layers (rows) transverse to the longitudinal axis of the neural tube (Meves, 1973). The cells in the row right behind the pigment cells of the FE were shown to be ciliated (as one would expect if they were homologous to vertebrate retinal photoreceptors). On the contrary, other neurons in the CV also have cilia (Meves, 1973). Moreover, the ciliary morphology was not as complex as the structure of ciliary photoreceptors in the vertebrate retina. Detailed anatomy of the FE was described in 12.5 day old $B$. floridae larvae using reconstructions of EM data of the CV (Lacalli, 1996; Lacalli. et al., 1994). In spite of the scarcity of data, it is likely that the structure of the FE in young larvae or in adult amphioxus does not differ much. The only observed change was enlargement of the FE pigment spot during larval growth (Wicht and Lacalli, 2005). Detailed studies performed on larvae of $B$. floridae 12.5 day old larvae provided strong evidence for possible homology between the FE and vertebrate lateral eyes (Lacalli, 1996; Lacalli. et al., 1994). This homology was based on the assumption that cells posteriorly adjacent to pigment cells are photoreceptors, even though their ultrastructure is not as elaborate as for some other ciliary photoreceptors. The pigment cup was shown to be formed of 3 rows, each consisting of 3 pigment cells. The cells located dorsally from the pigment cells form a series of morphologically slightly distinct transverse rows. They were numbered from anterior to posterior by numbers $1-4$. Five Row1 cells were described as putative ciliary photoreceptors. Row2 cells (10 in total) were also shown to bear cilia, but they probably serve as interneurons 
instead of acting as photoreceptors. Row3 and Row4 cells evinced a neuronal character, possibly serving as interneurons (see Fig. 3 for summary). Since the photoreceptor cells in amphioxus FE are arranged in single row, their receptor field is one dimensional.

Despite the difficulties in defining homology between amphioxus CV and vertebrate brain (Albuixech-Crespo et al., 2017), the homology between FE and vertebrate eyes appears simpler. Amphioxus orthologues of transcription factors important for development of vertebrate retinal neurons and retinal pigmented epithelium (RPE) were found to be expressed in the developing FE (Vopalensky et al., 2012). Molecular analysis uncovered distinct gene expression fingerprints for pigmented cells of the FE, for putative FE photoreceptors (Row1 cells) and for FE interneurons (Rows2-4). More specifically Otx was shown to be expressed in Row1 photoreceptors and in pigment cells; Pax4/6 was detected in Row1 photoreceptors and Row 3 and 4 cells, Rx is probably expressed in Row 1 photoreceptors and later in developing Row3 and Row4 cells and Pax2/5/8 and Mitf expression was documented in pigment cells (Fig. 3) (Glardon et al., 1998; Kozmik et al., 1999; Vopalensky et al., 2012; Williams and Holland, 1996). Otx and Pax4/6 expression
Fig. 3. Molecular fingerprint of amphioxus frontal eye cells and scheme of their proposed homology to vertebrate retinal cell types. (A) Anterior part of 4 days old larvae of $\mathrm{B}$. lanceolatum. Dashed rectangle marks region depicted in detail in (B-F). (B) Lateral view of larvae stained with antibodies against amphiOtx, amphiPax4/6 and 5HT. Cyan arrowhead points to Pigment cell; orange arrowhead points to Row 1 photoreceptor cells; red-blue hatched arrow points to Row2 cells; blue-white hatched arrowhead points to Row3 cells; red-white hatched arrowhead points to Row4 cells. (C) Dorsal view of area marked in (A). Larvae was stained with anti Pax4/6 antibody. Pax4/6 positive Row3 and Row4 cells are highlighted. (D) Lateral view of larvae stained with antibodies against amphiOtx, 5 HT and glutamate. (E) Lateral view of larvae stained with antibodies against amphiOtx, 5HT and glutamate. Different optical section than in $D$ was chosen to show Glutamate reactivity of Row3 cells. (F) Dorsal view of larvae stained with antibodies against amphiOtx, 5HT and glutamate. (G) Scheme of proposed homologies between particular cell types in amphioxus FE and vertebrate retina. For vertebrate retinal cell types specifying transcription factors, only selection of homeodomain transcription factors is depicted, to simplify the comparison with expression pattern of amphioxus FE cell types (expression of only homeodomain transcription factors was mapped in FE on single cell resolution, for details see Vopalensky et al., (2012)). Rx expression in Row 1 photoreceptors cells was not confirmed with antibody staining and is therefore marked with a "?".The proposed homology between amphioxus Row2, 3\& 4 cells and vertebrate retinal interneurons includes also data from EM analysis, which were mapping the projections of amphioxus FE neurons (Lacalli, 1996). Data about vertebrate cell types come from Bassett and Wallace (2012), Kolb (2011) and Swaroop et al., (2010). Anti amphiOtx and amphiPax4/6 antibodies were used from study by Vopalensky et al., (2012). Anti-5HT antibody - Abcam ab66047; Anti-Glutamate antibody Abcam ab120049.
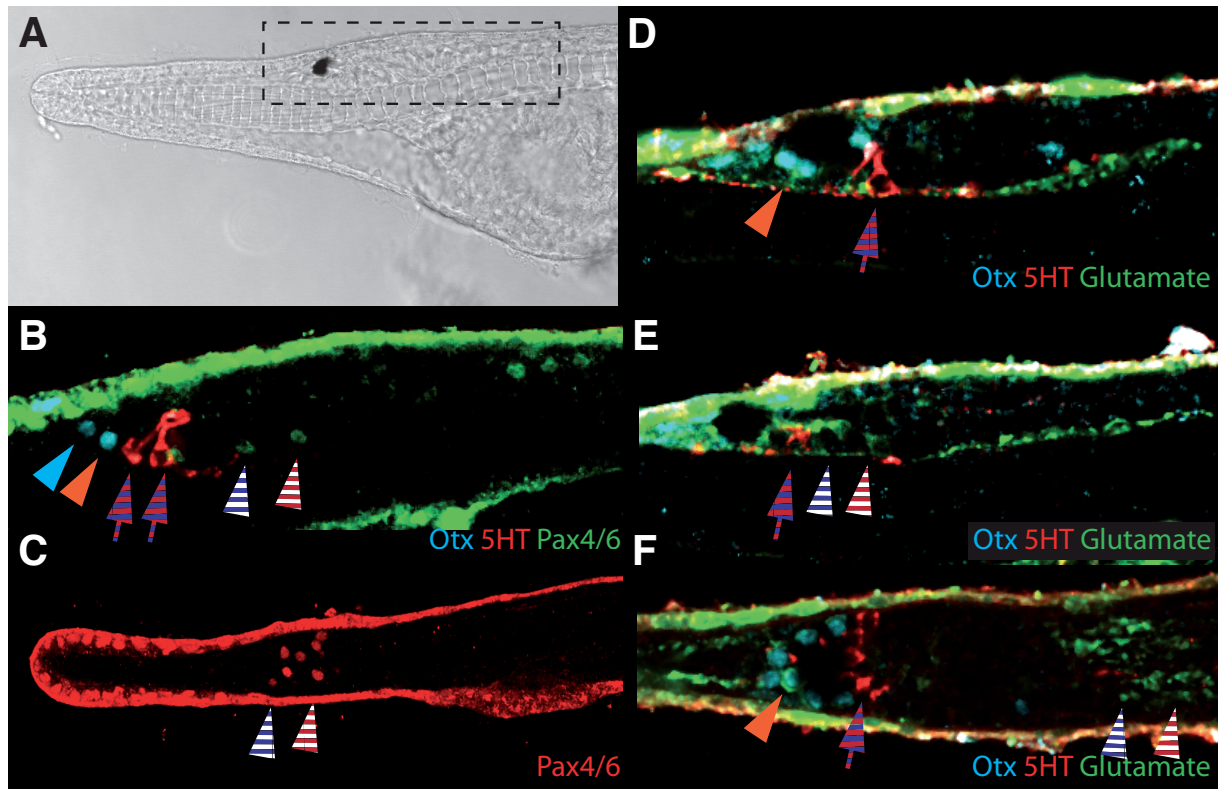

G Amphioxus Frontal eye
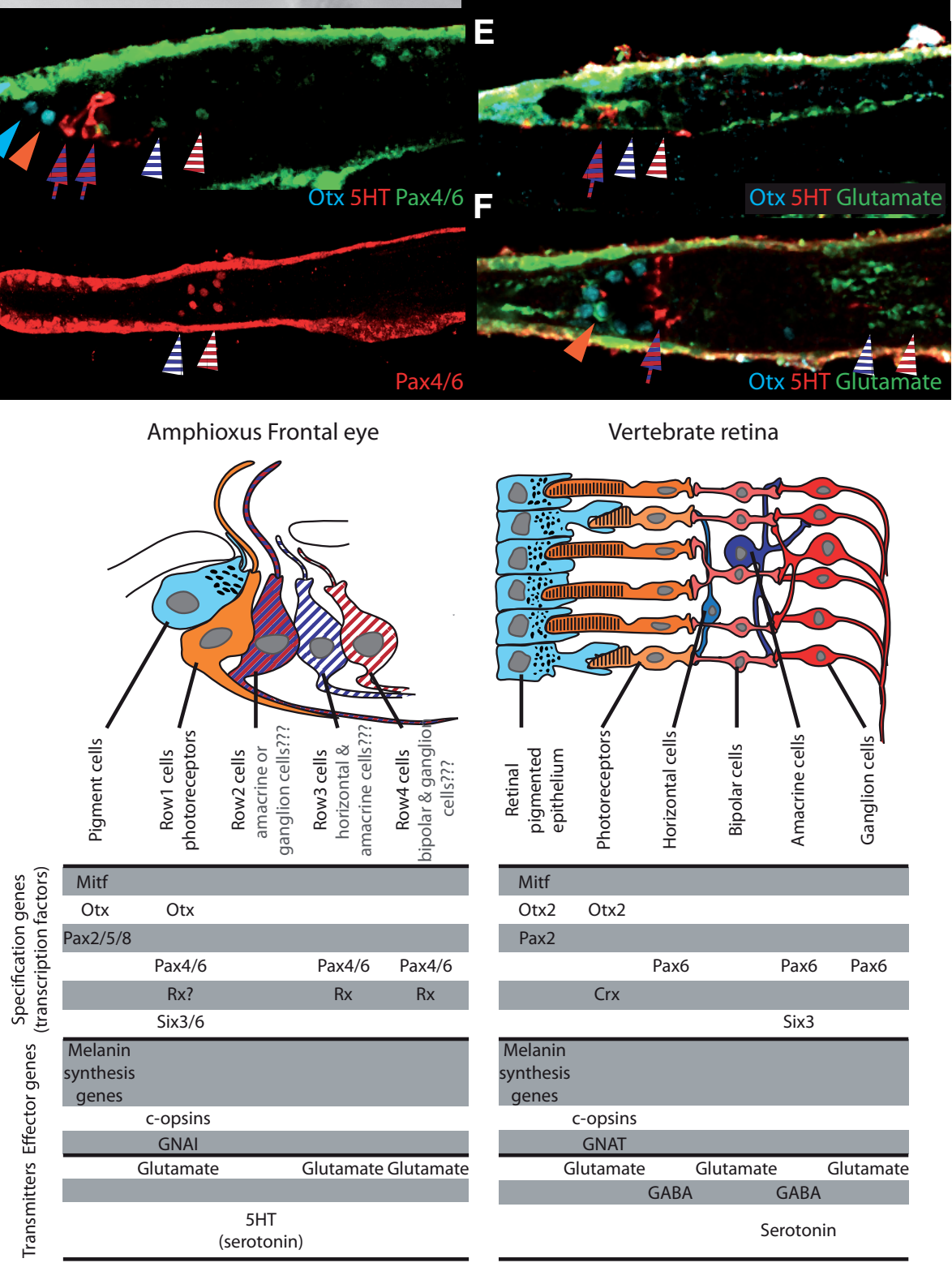
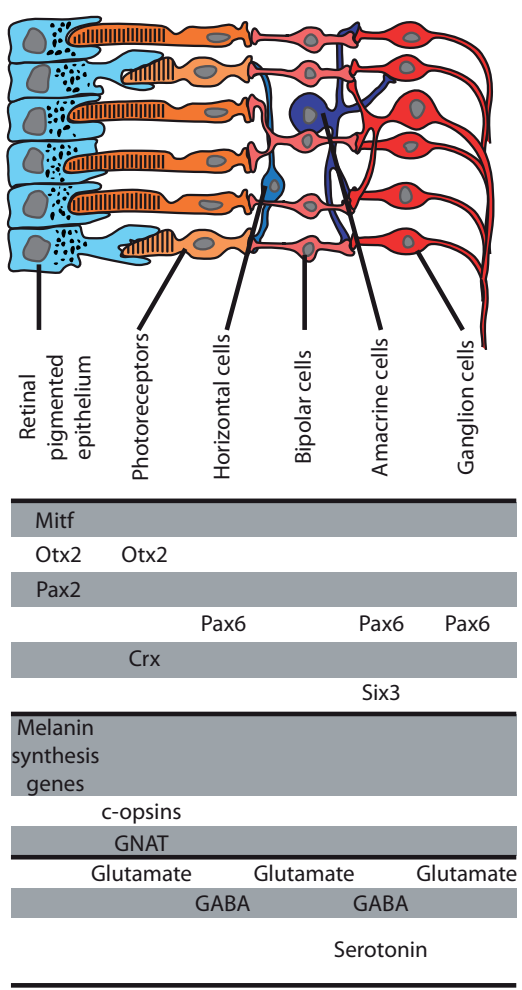
starts early in amphioxus development (at mid-neurula), being important for the development of major parts of the CV (Glardon et al., 1998; Williams and Holland, 1996). Later in development, expression of both genes becomes more restricted to particular cells of the developing FE (Vopalensky et al., 2012). The earliest expression of Rx starts at late neurula stage in the anterior tip of the $\mathrm{CV}$, probably in developing Row1 photoreceptor cells. During the course of development, the expression of Rx and Pax4/6 shifts more posteriorly to Row3 and Row4 cells. Next, expression of Six3/6, the amphioxus orthologue of the vertebrate Six 3 and Six 6 genes involved in eye development, was documented in the developing FE (Kozmik et al., 2007). Six3/6 and Pax4/6 were shown to be expressed in neurons of the primary motor center (PMC) - anteriormost motoneurons, probably reacting to signals coming from the FE (Kozmik et al., 2007; Vopalensky et al., 2012). Based on BrdU staining, so-called dorsal compartment motoneurons (probably responsible for control of muscular movements during swimming (Bardet et al., 2005; Wicht and Lacalli, 2005)), located posteriorly to the CV, seem to be differentiated early in development (at midneurula stage), while the neurons of FE are still developing (Holland and Holland 2006). The expression of Pax6 was shown to be exclusive to parts of the CV weakly stained with BrdU, confirming the role of Pax6 in neuronal differentiation in the FE (Kozmik et al., 2007). Our data provide evidence for glutamate immunoreactivity of FE photoreceptors (Fig. 3) and confirmed prediction made by Lacalli and Candiani (2017). Vertebrate photoreceptors display the same glutamate immunoreactivity (Connaughton, 2005).

Based on expression of c-opsins and presence of neurotransmitters, the differentiation of FE photoreceptors seems to be completed as soon as the larvae begin to feed (Vopalensky et al., 2012). This, combined with data from behavioral studies (Stokes and Holland, 1995), supports the possible role of the FE in feeding behavior. Expression of two amphioxus c-opsins (Op1 and Op3) was detected in FE photoreceptors, corroborating their ciliary character. In addition, expression of each of the opsins was detected in morphologically distinct cells, pointing to possible spectral diversity of amphioxus FE photoreceptors (Vopalensky et al., 2012). As stated above, amphioxus c-opsins form a sister group to vertebrate c-opsins. The origin of vertebrate specific c-opsins is still not resolved. It is, however, clear that the primary structure of vertebrate opsins underwent several optimizations to achieve higher activation potential, different spectral sensitivity and higher affinity for 11-cis retinal (Terakita et al., 2004; Tsukamoto et al., 2005). The downstream phototransduction cascade also appears to have been modified in the course of evolution. Transducin (Gat or GNAT), the $\mathrm{G} \alpha$ subunit of trimeric $\mathrm{G}$ proteins, mediating phototransduction cascade in vertebrate rods and cones, was not found in the amphioxus genome (Vopalensky et al., 2012). Its role in

A ciliary-like phototransduction in amphioxus $\mathrm{FE}$ is replaced by action of the GNAI subunit (Vopalensky et al., 2012). It was shown that GNAT can be found only in the genomes of vertebrates, and it most likely originated by tandem duplication of the GNAI gene. Ancient GNAT then underwent quadruplication during the 2RWGD (Lamb and Hunt, 2017; Lamb et al., 2016; Larhammar et al., 2009). In vertebrates two different GNATs (GNAT1 and GNAT2) participate in rod and cone phototransduction, respectively. A third gene, gustducin (GNAT3), is utilized in taste receptor cells. Interestingly GNAT3/X (lamprey homolog of vertebrate GNAT3) is probably involved in phototransduction cascade of lamprey photoreceptors (Lamb and Hunt, 2017). The appearance of GNAT gene in vertebrates also led to changes in the phototransduction cascade. Vertebrates use cGMP as a second messenger in both rods and cones. After light absorption, GNAT activates a phosphodiesterase that is responsible for decreasing the cGMP level, cGMP-sensitive CNG channels are closed, leading to hyperpolarization of the photoreceptor cell. This cascade is the same for all vertebrate ciliary photoreceptors examined to date (Fig. 4A) (Lamb, 2013). Recently, the existence of a distinct phototransduction cascade for amphioxus FE photoreceptors was proposed, based on gene inventory (Lamb and Hunt, 2017). Phototransduction starts with GNAI that inhibits adenylate cyclase which is responsible for synthesis of CAMP. Inhibition of synthesis of cAMP together with continuous activity of PDE leads to a decrease in cAMP, closure
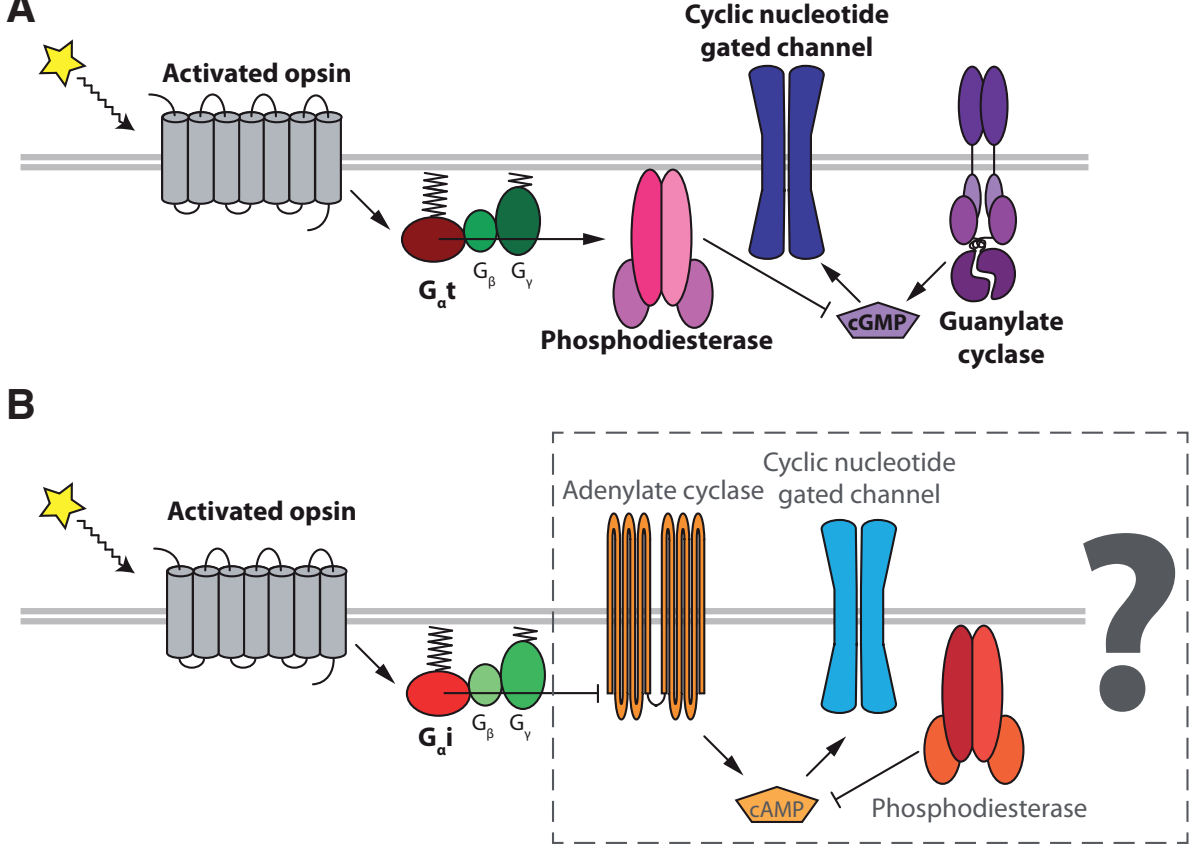

Fig. 4. Comparison of phototransduction cascade in vertebrate rods $\&$ cones and proposed phototransduction cascade in amphioxus frontal eye (FE) photoreceptors. (A) Phototransduction cascade in vertebrate photoreceptors. The cascade starts with stimulation of opsin and continues with activation of GNAT. Next GNAT stimulates phosphodiesterase (PDE), which degrades CGMP. Decrease of CGMP intracellular level leads to closure of CNG channels. (B) Recently proposed phototransduction cascade for amphioxus FE photoreceptors (Lamb and Hunt, 2017). The cascade starts with stimulation of opsin and continues with activation of GNAI. GNAl inhibits adenylate cyclase, which leads, in combination with continuous activity of PDE, to decrease in the level of intracellular CAMP. Subsequently CNG channels are closed and the cell hyperpolarize. Identified members of cascade are written in bold black, while proposed members are written in grey and framed by dashed rectangle. 
of CNG channels, and hyperpolarization of the FE photoreceptor cell (Fig. 4B). Experimental support of this hypothetical cascade has not yet been provided, and only the expression of GNAI in the FE photoreceptors has been confirmed.

The proposed homology of amphioxus pigment cells and Row1 photoreceptors cells with vertebrate RPE and photoreceptors respectively is relatively well supported. However, the homology between putative amphioxus interneurons within the FE and particular classes of vertebrate retinal interneurons remains elusive. Differentiated Row2 cells were shown to be serotonin positive (Candiani et al., 2012; Vopalensky et al., 2012). In the vertebrate retina, a distinct class of amacrine cells is serotonin positive, but the role of serotonin as a neurotransmitter has not been confirmed (Kolb, 2011). On the other hand, Row2 cells send terminals to the presumptive "visual processing" center of the CV (Vopalensky et al., 2012), pointing to homology with vertebrate retinal ganglion cells. The Row2 cell projections are, however, ipsilateral (Lacalli, 1996), while most ganglion cells in the vertebrate optic nerve project contralaterally. Moreover Row2 fibers seem to form irregular terminals and do not show any sign of definitive neuronal synapses (Lacalli, 1996). Contralateral projections in amphioxus are instead sent by Row4 cells (Lacalli, 1996). This would suggest homology between Row4 and retinal ganglion cells. Additional insight supporting the formerly proposed homology between Row2 and vertebrate retinal ganglion cells has been obtained by comparison of amphioxus and lamprey visual processes (Suzuki et al., 2015). In lamprey, there is a fundamental difference between larval and adult eyes.
The larval eyes have a simple bi-layered retina and lack a lens, being covered with translucent skin. Lamprey larval eyes are thus reminiscent of the eyes of hagfish. During metamorphosis, lamprey eyes become more complex anatomically and physiologically, coming to resemble those of higher vertebrates. Comparison of neural circuits and brain patterning between amphioxus and larval and adult lamprey (Lethenteron camtschaticum) has pointed to similarities and probably evolutionarily conserved characters (Suzuki et al., 2015). In both amphioxus and lamprey, the photoreceptors develop in Otx- and Pax6-positive regions in the presumptive prosencephalon. Next, the signal is transmitted by neurons sending processes to integrative neurons in Pax6-positive presumptive prosencephalic region in amphioxus and larval lamprey. This seems to be the ancestral state from which, by additional modification, the current vertebrate visual circuitry evolved. This improved circuitry can be found in adult lamprey and jawed vertebrates, where the signal is transmitted to a tectum, localized in a mesencephalic region defined by Pax2 and Engrailed expression. New data, however, show that the amphioxus $\mathrm{CV}$ exhibits characteristics typical of both diencephalon and mesencephalon without clear distinguishableborders (Albuixech-Crespo et al., 2017). This would also be supported by the proposed visual circuitry in amphioxus, where the projecting Row2 neurons send their processes to the Di-Mesencephalic part of CV. It would, however, change the view on evolution of vertebrate visual circuitry presented earlier (Suzuki et al., 2015). In the more-recently proposed scenario, projection to the mesencephalon would be the evolutionarily-conserved state,

\section{A}
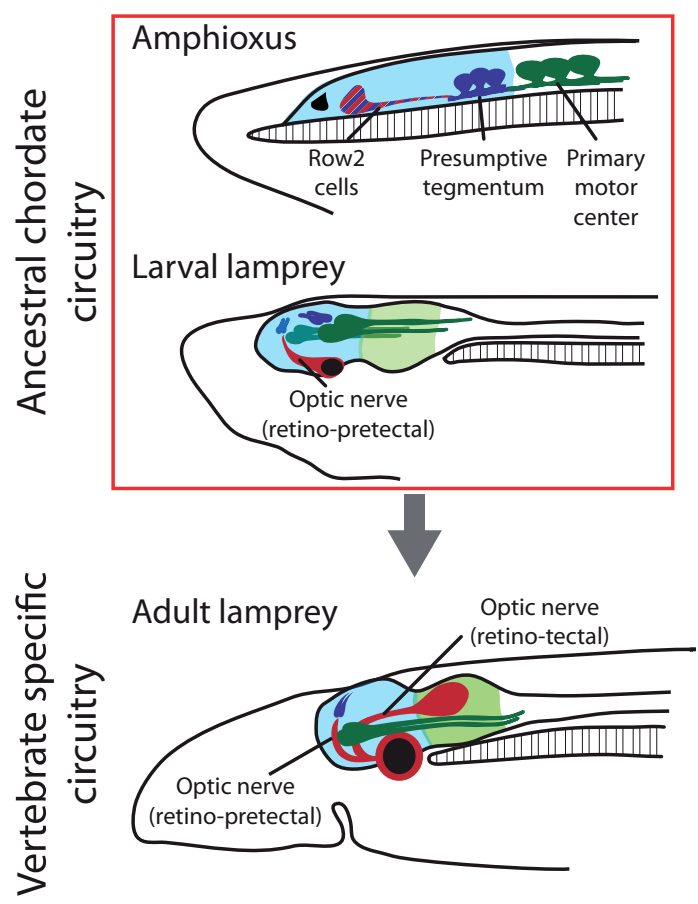

B Scenario after Albuixech-Crespo et al., 2017

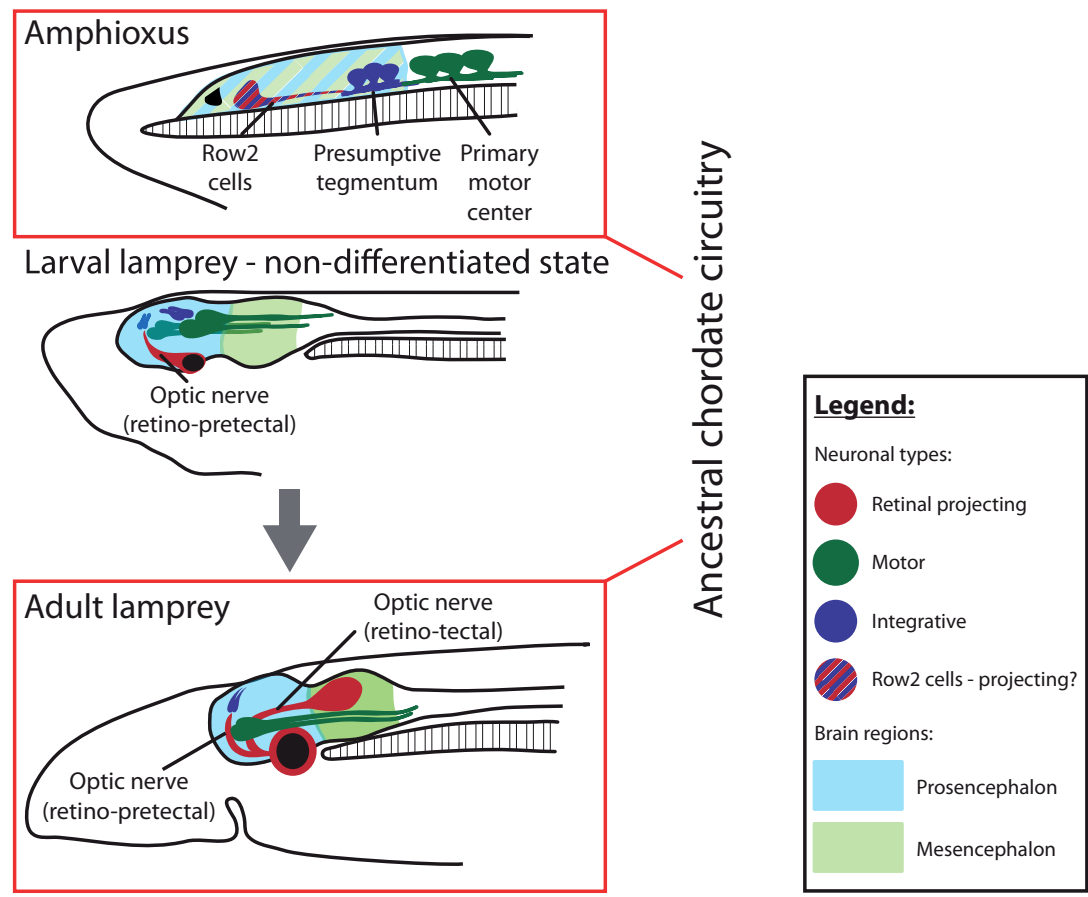

Fig. 5. Possible scenarios for evolution of vertebrate specific visual circuitry. (A) First scenario was proposed by Suzuki et al., (2015). According to this scenario ancestral state for visual circuitry in all chordates would be transmission of signal from photoreceptors to visual processing center localized in prosencephalic-like Pax-6 positive part of the brain. On the other hand, (B) new data showed, that developing CV of amphioxus displays characteristics common for both prosencephalon (more specifically diencephalon) and mesencephalon in the same time (Albuixech-Crespo et al., 2017). This would suggest, that ancestral chordate state of visual circuits is transmission of signal from photoreceptors to mesencephalic part of the brain. The situation in larval lamprey would thus represent not fully differentiated state. 


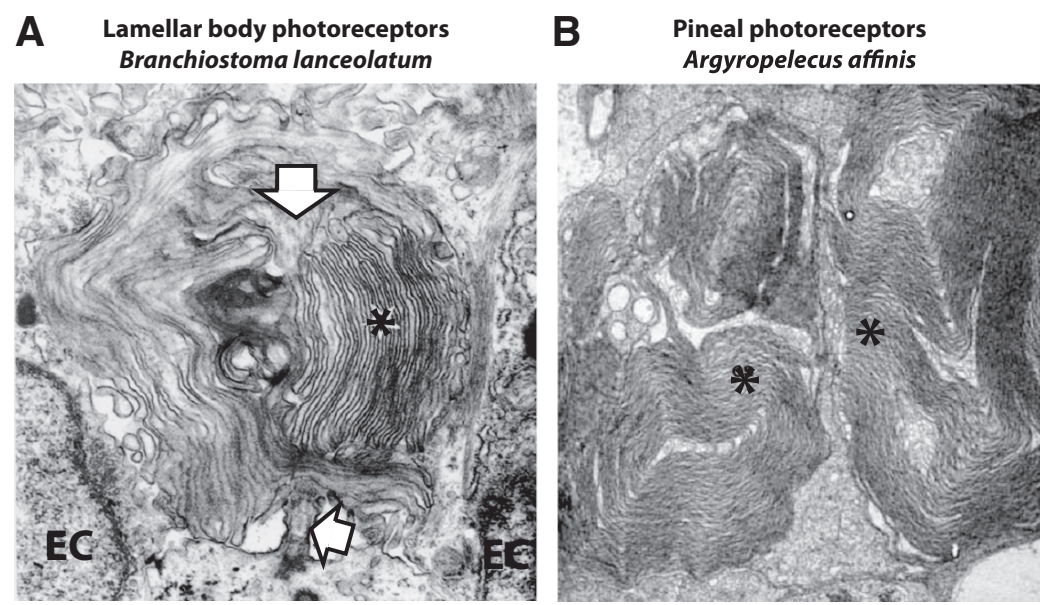

Fig. 6. Ultrastructure of photoreceptors of amphioxus lamellar body and vertebrate pineal gland. Electron microscopical photography of amphioxus lamellar body photoreceptors (A) and photoreceptors of pineal organ in fish Argyropelecus affinis (B). Asterisks (*) mark the membranous lamellae that are conspicuously similar in both photoreceptor types. Arrows in (A) mark cilium from which lamellae in amphioxus lamellate cells arise. EC, ependymal cells adjacent to lamellate cells. Photo of amphioxus lamellate cells used with permission of the publisher from Ruiz and Anadon (1991b). Photo of Argyropelecus affinis pineal photoreceptors used with permission of the publisher from Bowmaker and Wagner (2004).

being present already in the chordate ancestor (Albuixech-Crespo et al., 2017), while the nerve projection of eyes in larval lamprey would represent an incompletely-developed state (see Fig. 5 for comparison of the two proposed scenarios).

In conclusion, it seems that the homology that was proposed long ago between the amphioxus FE and vertebrate lateral eyes (Kemna, 1904), receives additional support from newly-available molecular data. Based on expression profiles, and despite their simple ultrastructure, amphioxus FE photoreceptors seem to be homologs of vertebrate rods and cones, and might represent a form of photoreceptor found in a common chordate ancestor. The difference in ultrastructure between FE photoreceptors and rods and cones is, however, striking. It seems evident that the expansion of membrane in rods and cones lead to improved photon absorption and thus enabled progress of high spatial resolution (Nilsson, 2013). This was arguably one of the crucial steps in the arms race between predators and prey during evolution. The expanded surface area of photoreceptors, as well as the above mentioned changes in opsin structure and in the phototransduction cascade, enabled higher sensitivity and resolution in the eyes of an ancestor of vertebrates. To confirm this hypothesis, more experimental data is required about physiology and the phototransduction cascade in the photoreceptors of the amphioxus FE.

\section{Lamellar body}

Of the four known amphioxus photoreceptive organs, the LB is the one with the least information about its development, molecular markers and physiology. On the other hand, relatively strong morphological evidence supports homology between the LB and its putative vertebrate counterpart, the pineal organ. The function of the LB as a possible photoreceptive organ was noted for the first time by Satir in 1958 (unpublished results mentioned in Eakin and Westfall, 1962a). The ultrastructure of lamellate cells was, at that time, confusing, because it did not show similarity with vertebrate retinal photoreceptors. While rod and cones membrane processes are perpendicular to the cilium they arise from, the membranous processes of lamellate cells are parallel with the cilium (Eakin and Westfall, 1962a). This arrangement is typical for vertebrate pineal photoreceptors (Ruiz and Anadon, 1991b) and the lamellar body was (and still is) thus considered as a homolog of the vertebrate pineal organ (Lacalli. et al., 1994; Nakao, 1964). The similarity of photoreceptor ultrastructure between pineal and LB photoreceptors is indeed striking (see Fig. 6). The ciliary structure of the lamellate cells was, however, questioned after observations arguing that the membranous folds of lamellate cells come directly from the cell membrane and not from the modified cilium (Meves, 1973). Detailed EM analysis, nonetheless, confirmed the ciliary character of the membranous appendages of the lamellate cells, showing that the main cilium they arise from contains a 9+2 microtubule structure (Ruiz and Anadon, 1991b) (interestingly this structure is typical for motile cilia, for review about cilia structure see Satir and Christensen (2008)). Moreover each of the membranous appendages is supported by accessory microtubules that are not derived from the basal axonema.

Almostnothing is known about the gene regulatory network involved in development of the LB in amphioxus. Development of the LB starts probably at mid-neurula stage from the posterior part of a Pax6-positive domain of the CV (Glardon et al., 1998). Pax6 is expressed in the lamellar body region at least to the two and half gill slit larvae stage in B. floridae (Vopalensky et al., 2012). In vertebrates, Crx was shown to be involved in development of both lateral eyes and pineal organ. Expression of amphioxus Otx, the homolog of vertebrate Crx, was however not detected in the developing LB (Vopalensky et al., 2012). Of the four amphioxus c-opsins examined, none was found to be expressed in the LB (Vopalensky et al., 2012). It is therefore difficult to determine when the cells of the LB become photosensitive or if they ever become photoreceptors.

Recent data showed that lamellate cells can be detected as early as in the first gill slit larvae of $B$. floridae (Bozzo et al., 2017). The number of cells forming the lamellar body increases during larval development from about 6 cells in 1 gill slit larvae, through 8 cells in 2 gill slits larvae to about 40 in 12.5 days old larvae of $B$. floridae (Bozzo et al., 2017; Lacalli. et al., 1994). The development of the LB correlates strikingly with the appearance of photosensitive behavior in larvae and is thus most likely responsible for initial light response of amphioxus larvae (Lacalli. et al., 1994). Moreover lamellate cells in larvae probably send processes to the amphioxus tegmentum, and are involved in modifying the switch between different modes of swimming (for information about current views on locomotory circuits in amphioxus see Lacalli and Candiani (2017)). It seems that the LB processes might repress the startle reaction and contribute to the hovering of larvae during swimming. Later in development compact LB disaggregates (possibly due to forward expansion of JCs), since only scattered lamellate cells were detected in adults (Castro et al., 2015; Meves, 1973). As described earlier, amphioxus larvae display a typical circadian rhythm guided behavior (diurnal migration), while adults live mostly borrowed in the sand during both day and night. Presence of compact LB in amphioxus larvae 
(and not in adults) supports its proposed homology with the pineal organ. The pineal organ in vertebrates is important for maintaining the circadian rhythm and so is probably the LB in amphioxus larvae. Amphioxus adults still exhibit higher activity during the night, but the photoreceptors responsible for circadian rhythm control are more likely JCs than the LB (see section about JCs for more details). We hypothesize that the LB is thus more needed and therefore more developed in larvae than in adults.

Of special interest is the close proximity of lamellate cells and Joseph cells. In later developmental stages the JCs grow over the lamellate cells and cover them. The connection between JCs and lamellate cells (rhabdomeric and ciliary photoreceptors in close proximity) puzzled scientists for long time. It led to proposals about similarity with vertebrate retina where rods and cones (ciliary photoreceptors) and ipRGCs (rhabdomeric-like photoreceptors) are closely associated (Ruiz and Anadon, 1991b). Lamb (2013) came with a hypothesis, that close proximity of ciliary and rhabdomeric photoreceptors led to synaptic transmission between them, and in due course the rhabdomeric cells became projecting neurons (ganglion cells). Close spatial association was noted also between distinct photoreceptors of some ascidians. In this case, the ciliary and rhabdomeric photoreceptors are however present at different stages of development (Ruiz and Anadon, 1991b). Due to limited data regarding both $\mathrm{LB}$ and $\mathrm{JCs}$, their possible functional cooperation remains elusive.

Taken together, the features of the LB (photoreceptor ultrastructure, development correlated with light-guided larval behavior and localization in the posterior part of the $\mathrm{CV}$ ) strongly support its homology with vertebrate pineal organ. It is interesting that while in vertebrates the pineal gland is retained for the entire life, the LB in amphioxus disaggregates (and might thus loose some of its photoreceptive function) in adults. The striking similarity between photoreceptors of the LB and the vertebrate pineal organ led to the proposal that their ultrastructure (optimized for maximizing light absorption) was retained during the course of evolution, probably due to their optimal anatomy to function in dim light (Lacalli, 2008). This is more remarkable when one compares the changes in ultrastructure undergone by the ancestral chordate photoreceptors on the way to more elaborate ciliary photoreceptors in vertebrate retina during the course of evolution. The homology between the amphioxus LB and vertebrate pineal organ suggested by morphology should be examined further with additional data from developmental genetics and physiology.

\section{Rhabdomeric photoreceptors}

Two photoreceptive organs with rhabdomeric morphology develop in amphioxus - the dorsal ocelli (DO, sometimes also called organs of Hesse) and Joseph cells (JCs). Rhabdomeric photoreceptors (with microvilli membrane protrusions) are typical visual photoreceptors in invertebrates. In vertebrates the ipRGCs, which are considered as remnants of ancestral chordate rhabdomericlike photoreceptors, do not have microvilli at their surface. To date, there is still an ongoing debate whether the DO and JCs are more closely homologous to vertebrate ipRGCs (which have been shown to be involved in circadian rhythm and pupillary reflex) or invertebrate photoreceptors. The DO and JCs share some common features. Nevertheless some important differences exist in their development, physiology and morphology, so when appropriate we will deal with the DO and the JCs separately. The first obvious difference between the JCs and the DO is that each dorsal ocellus consists of one photoreceptor cell and one pigment cell, and is thus directional photoreceptor, while the JCs lack pigment and are thus non-directional photoreceptors. Due to the presence of pigment, the DO were already connected with photoreceptive behavior at the turn of $20^{\text {th }}$ century (Hesse, 1898; Parker, 1908). Boveri (1904) even proposed a scenario, saying that $\mathrm{DO}$ were evolutionary precursors of vertebrate lateral eyes, which would arise from DO by their aggregation into complex organ. This suggestion was however soon negated by Kemna (1904) (and later also by Jelgersma (1906)), showing that DO were missing along the cerebral vesicle in the right place to give rise to vertebrate lateral eyes. A description of the JCs had also been provided early in the $20^{\text {th }}$ century (Joseph, 1904), but due to lack of pigment, they were neglected from studies dealing with photoreceptive behavior in amphioxus.

The first DO is already developing at mid-neurula stage, as the first photoreceptive organ in amphioxus. The role of this first DO in phototaxis is, however, unknown. Development of additional DO follow soon after the development of other photoreceptive organs at mid-larval stages. Intriguingly there is an anatomical difference between the first DO and all of those that develop subsequently. The first DO consists of two photoreceptor cells, with one pigment cell intercalated between them (Fig. 7A-C), while the subsequently developing $\mathrm{DO}$ are formed by one photoreceptor cell and one adjacent pigment cell (Fig. 7D). The reason for this difference is not known. The DO are located along the entire length of the neural tube, beginning from the border between the neural tube and the CV at approximately the third myotome (Nakao, 1964). The fact that the DO are not present in much of the CV was the reason for aforementioned dispute between Boveri (1904) and Kemna (1904) about possible role of the DO in evolution of vertebrate lateral eyes. The DO are located laterally or ventrally from the central canal on each side of the neural tube (Hesse, 1898). Amphioxus body segments on the right side are shifted by half of one segment posteriorly relative to those on the left side, and a corresponding shift is observed for the DO on the right side relative to those on the left side. Longitudinally the distribution of the DO varies along the neural tube, being highest in the anterior, lowest in the middle part of neural tube and increasing in numbers again in the most posterior part. They are arranged in clusters along the neural tube, with the first cluster consisting of only two DO on each side of the neural tube, and gradually increasing from the fourth myotome to about 25 on each side of the neural tube. In total, about 1500 DO can be found on each side of the neural tube in the adult amphioxus (Nakao, 1964), making them the most abundant type of photoreceptors in adult amphioxus. It was noted initially that most of the DO look slightly to the right side to be oriented to light coming from the right side (Hesse, 1898). Franz (1923) provided detailed analysis of orientation of DO on transversal and longitudinal sections. DO laying ventrally from neural tube central canal face ventrally, those laying on the left from central canal face upwards slightly to right and those laying on the right side face right downwards. The functional meaning of the asymmetric arrangement is however not clear. The distribution of DO is well correlated with the light intensity necessary to evoke stimulation of adult amphioxus. The anterior region of the neural tube appears to be the most lightsensitive, followed by the posterior part (that being only slightly less sensitive). In contrast, the middle part of the neural tube is about 
ten times less sensitive compared to the anterior region (Parker, 1908; Sergeev, 1963). It is generally accepted that DO might be necessary to provide an adult amphioxus with information about how deep its body is buried in the sand, and DO are exclusively adapted to this task (Lacalli, 2004).

Limited information exists about the gene expression profile of DO. Apart from melanopsin, that serves as the best defining marker and key physiological component of amphioxus DO (as well as JC) photoreceptors (Koyanagi et al., 2005), only the gene encoding estrogen-related receptor (ERR) was unequivocally found to be expressed in the two photoreceptors of the first DO and interestingly also in dorsal compartment motoneurons (Bardet et al., 2005). These were shown to be innervated by the $1^{\text {st }} \mathrm{DO}$ (Lacalli, 2002). Several studies focused on transcription factors known to be involved in development of vertebrate and invertebrate visual systems, such as the members of the Drosophila retinal determination gene network (RDGN) (Davis and Rebay, 2017). Expression of amphioxus RDGN orthologous genes belonging to Pax, Six, Eya and Dach families, respectively, was investigated by whole mount in situ hybridization at various stages of embryonic development. Notably, Pax6 expression was not detected in developing first or subsequent DO (Glardon et al., 1998), placing DO among those animal photoreceptive organs whose formation is independent of Pax6 function. Instead, the area from which the first DO develops expresses Pax2/5/8 during the neurula stage (Kozmik et al., 1999). At later developmental stages scarce Pax2/5/8 (Kozmik et al., 1999) and Dach (Kozmik et al., 2007) expression was detected along the neural tube - whether this expression is localized to differentiating pigment or photoreceptor cells of the subsequently developing DO remains to be determined. Transient expression of Six $4 / 5$ and Eya was detected in the amphioxus neurula in two cells in the region where the first DO develops (Kozmik et al., 2007). Co-expression analysis with specific markers such as melanopsin is needed to confirm that these cells indeed represent the two developing photoreceptors of the first DO. Expression of genes known from the pigment synthesis cascade in the vertebrate retinal pigment epithelium (namely Mitf, Tyrp-a, Tyrp-b and Tyrosinase) was detected in the area of the pigment cell of the first DO (Vopalensky et al., 2012; Yu et al., 2008) and the black pigment was melanin (Vopalensky et al., 2012). These results indicate that the same cascade is used for the synthesis of the shielding pigment in amphioxus and vertebrates. Moreover it showed that the same pigmentation cascade is used for two distinct photoreceptive organs (the FE and DO) in amphioxus (Vopalensky et al., 2012).

The development of JCs is not as well documented as the development of DO. The first description of JCs was made in adult amphioxus (Joseph, 1904; Ruiz and Anadon, 1991a; Watanabe and Yoshida, 1986; Welsch, 1968). So far, however, no study aimed at identifying their advent in earlier stages. JCs are known to develop in the dorso-caudal part of the CV (Ruiz and Anadon, 1991a). In larvae, JCs are probably located posterior to the LB, while in adults the JCs form a cap above the scarce lamellate cells. About 400-450 JCs are present in the adult amphioxus (Castro et al., 2015). Studies of the ultrastructure of JCs confirmed their rhabdomeric character. JCs are about 15 um in diameter and oval in shape. Their microvilli extend over most of the cell surface and are enclosed by surrounding glial cells. One or two cilia with $9+0$ structure emanate from the membrane of each $\mathrm{JC}$, but these are not related to rhabdom structure. Interestingly, notable differences in rhabdom structure were observed between dark-adapted and light-adapted JCs. In dark-adapted JCs, the microvilli are thinner, more numerous and more regularly arranged compared to light
Fig. 7. Melanopsin expression in amphioxus dorsal ocelli (or Hesse organs) and ultrastructure of dorsal ocellus (DO). (A) Detail of melanopsin expression in $1^{\text {st }}$ dorsal ocellus in 2 days old $\mathrm{B}$. floridae larvae. Red arrowhead points to photoreceptor cell, blue arrowhead points to pigment cell. Two photoreceptor cells forming the first dorsal ocelli are visible. (B) Electron microscopical photo of $1^{\text {st }}$ DO of 12.5 days old larva of $\mathrm{B}$. floridae. Photo used and adapted with permission of the publisher from Kozmik (2008). (C) Scheme of $1^{\text {st }} D O$ based on photo in B. (D) ultrastructure of $D O$ in adult $\mathrm{B}$. belcheri. Except for $1^{\text {st }} D O$ other DO are formed by one photoreceptor and one adjacent pigment cell. Borders of photoreceptor cell are marked with dashed red light. Borders of pigment cell are marked with dashed blue line. Microvilli in photoreceptor cell and pigment granules in pigment cell are highlighted. Photo used and adapted with permission of the publisher from Nakao (1964)
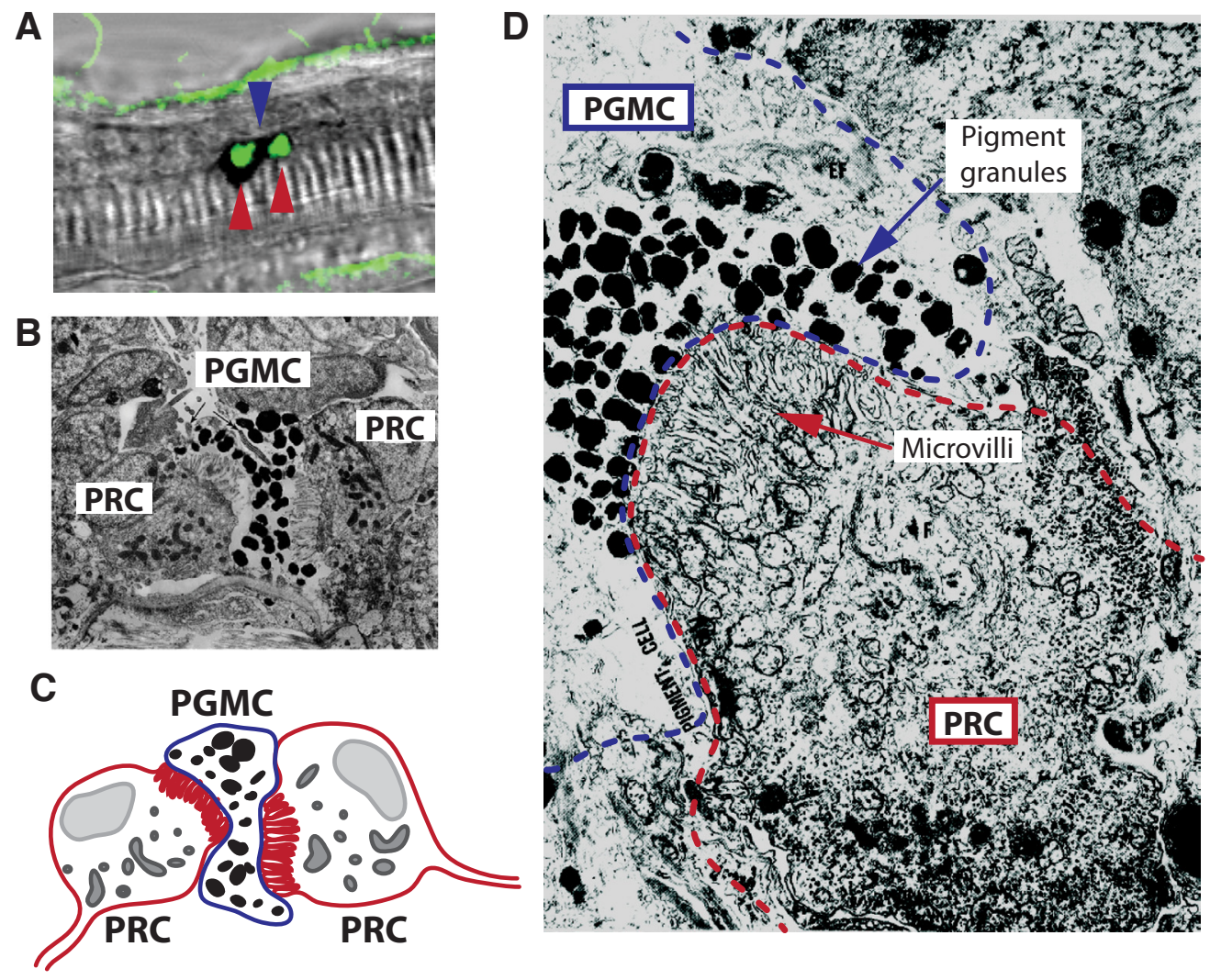
adapted JCs. Gross morphological changes were accompanied by changes of vesicle content in the cytoplasm. Similar changes in rhabdom structure and content of cytoplasmic granules were observed in photoreceptors of several invertebrate species (Arikawa et al., 1987; Arikawa et al., 1988; Hariyama et al., 2001; Sakura et al., 2003). Noticeably, the above-mentioned changes were shown to appear even in specimens kept in constant darkness, and are therefore likely regulated by circadian rhythm pathways rather than a direct response to light intensity. In case of JCs, however, no information is available about the effect of the light/dark cycle on rhabdom structure. It is noteworthy that while the LB disaggregates during development, the number of JCs and DO seems to increase. This would point to a switch of roles for maintenance of circadian rhythms from LB in larvae to JCs and/or DO in adult amphioxus. With the primary role of DO proposed to be in providing information about the vertical position of amphioxus within a burrow, the JCs seem to play the lead role in directing circadian rhythms in the adult amphioxus.

DO photoreceptor cells are described as having a single basal axon. The data from larvae showed that projections from the first DO are ipsilateral (Lacalli, 2002), whereas in adult amphioxus the projections from the DO are contralateral (Castro et al., 2006). Amphioxus larvae exhibit two different swimming modes - slow undulatory swimming involved mainly in vertical diurnal migration, and rapid muscular movement for escape (Guthrie, 1975; Lacalli and Kelly, 2003). Two different muscle types are probably involved in these reactions - superficial muscles involved in the slow swimming mode and deep muscle fibers responsible for the fast mode of swimming (Lacalli and Candiani, 2017; Lacalli, 2002). Tracking the axons of the first DO showed that they probably target exclusively dorsal compartment motoneurons involved in innervation of superficial fibers. The first DO is thus probably involved in controlling the slow swimming mode (Lacalli, 2002). However physiological recordings are needed to confirm this.

In JCs, some kind of axonal projections were detected but their exact terminals were not found (Welsch, 1968). More recent EM survey of juvenile amphioxus for JCs axon did not provide any positive results. It is, however, still possible, that JCs develop their processes later in development.

In contrast to FE photoreceptors, where at least two distinct ciliary opsins are present and the molecular details of the downstream cascade are not entirely resolved, the situation in DO and $\mathrm{JC}$ photoreceptors is better known. As stated above, melanopsin is the only opsin expressed in both classes of amphioxus rhabdomeric photoreceptive organ - JCs and DO (Koyanagi et al., 2005). Amphioxus melanopsin was shown to be bistable (Koyanagi et al., 2005). This means that upon irradiation, 11-cis-retinal is converted to all-trans-retinal, as is common for most opsins. However, the all-trans-retinal is not released from melanopsin, but is converted back to 11-cis-retinal after irradiation by absorption of another photon. This is a shared characteristic between all melanopsins and rhabdomeric opsins that have been studied. Amphioxus melanopsin has its maximum absorption in the blue part of the spectrum - between 470 and 485 nm (Gomez Mdel et al., 2009; Koyanagi et al., 2005), similar to vertebrate melanopsins.

The physiology and phototransduction cascade in isolated DO and JCs has been investigated in several studies (Acemel et al., 2016; Angueyra et al., 2012; Ferrer et al., 2012; Gomez Mdel et al., 2009; Nasi and del Pilar Gomez, 2009; Peinado et al., 2015; Pulido etal., 2012). These seminal studies not only confirmed that JCs and DO indeed function as photoreceptors, but also provided comparative data with respect to invertebrate rhabdomeric photoreceptors and ipRGCs. The irradiation of both cell types leads to depolarization and an increase in membrane conductance (Gomez Mdel et al., 2009). This is similar to the physiological changes observed in other invertebrate rhabdomeric photoreceptors and in vertebrate ipRGCs. After irradiation, the phototransduction cascade begins with activation of GNAQ (Bailes and Lucas, 2013; Gomez Mdel et al., 2009; Terakita et al., 2008). In support of this step of the cascade is the fact that GNAQ is co-expressed with melanopsin in both JCs and DO (Koyanagi et al., 2005). The ancient chordate GNAQ gene underwent quadruplication and specialization for various tasks after 2RWGD, as did the genes of the vertebrate GNAT family. Nevertheless, the core of the ipRGC phototransduction cascade (melanopsin activating member of GNAQ family) seems to be the same. The next step of the phototransduction cascade in JCs and DO is the activation of PLC and the hydrolysis of PIP2 to IP3 and DAG. The IP3 branch of PLC signaling was verified, while DAG seems to have minimal or no role in mediation of the conductance change (Angueyra et al., 2012). The situation in ipRGCs is more complicated, since neither IP3 nor DAG appears to be involved in the phototransduction cascade (Graham et al., 2008) (reviewed by Hughes et al., (2012)). Results of several studies suggest that PIP2 itself might act as second messenger in the ipRGC phototransduction cascade (reviewed by Hughes et al., (2012)). On the other hand, in invertebrate rhabdomeric photoreceptors, the detected downstream effectors of phototransduction cascade vary between species as well as within species. Proposed candidates include IP3 (Brown et al., 1984; Fein et al., 1984) or $\mathrm{Ca}^{2+}$ (Payne et al., 1986) in Limulus polyphemus; DAG or its metabolites, e.g. PUFAs (Chyb et al., 1999; del Pilar Gomez and Nasi, 1998; Delgado et al., 2014) in Drosophila or scallop; protons (Huang et al., 2010) and mechanical forces (Hardie and Franze, 2012) in Drosophila. The next step of the cascade, namely the role of TRP channels in $\mathrm{DO}$ and JCs photoconductance has been confirmed (Pulido et al., 2012) and appears similar to that in invertebrate photoreceptors and ipRGCs. For JCs and DO Na+ carries a substantial fraction of the photocurrent, while $\mathrm{Ca}^{2+}$ contribute only moderately to depolarization, and the role of $\mathrm{K}^{+}$appears to be minimal (Pulido et al., 2012). However, it has been shown in JCs and DO that an increase in the level of $\mathrm{Ca}^{2+}$ precedes the opening of the $\mathrm{Ca}^{2+}$ permeable TRP channels (Peinado et al., 2015). This also appears to occur in ipRGCs (Graham et al., 2008). Moreover the release of $\mathrm{Ca}^{2+}$ from internal stores in the ER has been detected in both JCs and DO (Angueyra et al., 2012). The opening of the TRP channels is thus probably mediated by an increase in the level of intracellular $\mathrm{Ca}^{2+}$ (Peinado et al., 2015), but more data are needed to confirm this. In sum, the reconstructed phototransduction cascade in JCs and DO seems to be as follows: melanopsin - GNAQ - IP3 - $\mathrm{Ca}^{2+}$ increase - opening of TRP channels $-\mathrm{Na}^{+}$and $\mathrm{Ca}^{2+}$ influx (Fig. 8). Moreover, presence of S-arrestin, involved in attenuation of phototransduction cascade in visual photoreceptors of invertebrates (Lieb et al., 1991) and vertebrates (Pfister et al., 1985) as well as in ipRGCs (Cameron and Robinson, 2014), has been reported in both JCs and DO (Mirshahi et al., 1985; van Veen et al., 1986). Because of discrepancies in descriptions of the phototransduction cascade in ipRGCs and invertebrate photoreceptors, it would be premature to assess which one is more similar to the cascade 
present in JCs and DO.

Despite similarities in the overall design among rhabdomerictype phototransduction cascades of vertebrates and invertebrates (including amphioxus) notable differences exist in the light sensitivity of the corresponding photoreceptors. Vertebrate ipRGCs do not have elaborate membrane protrusions (Sand et al., 2012) of the kind found in rhabdomeric photoreceptors, leading to less efficient photon capture. In agreement with this finding, ipRGCs are less sensitive than most invertebrate visual photoreceptors (Do and Yau, 2015). Amphioxus JCs and DO exhibit a photosensitivity somewhere between ipRGCs and invertebrate photoreceptors. It is estimated that JCs and DO express melanopsin at levels comparable to typical rhabdomeric photoreceptors, yet the gain of the photocascade upon irradiation is lower indicating that differences in phototransduction cascades are responsible for overall efficiency. In fact, although the TRP channels seems not to be the limiting factor, the number of TRP channels activated per photon was shown to be lower in DO and JC compared to invertebrate photoreceptors (Ferrer et al., 2012). The single photon sensitivity of JCs and DO is similar to that of ipRGCs. Nevertheless, due to their more elaborate morphology (typical rhabdomeric membrane protrusions) JCs and DO are overall more sensitive than ipRGCs, so they can provide better information about light conditions. On the other hand while the response of ipRGCs to illumination decays on the order of seconds (probably an adaptation for their role in control of circadian rhythm), the decay in response of $\mathrm{JCs}$ and $\mathrm{DO}$ is in the millisecond range (Ferrer etal., 2012). Amphioxus melanopsin-positive photoreceptors thus cannot function as circadian photoreceptors as effectively as ipRGCs. If one would consider amphioxus JCs and DO to resemble the ancestral state of melanopsin expressing photoreceptors in the
A

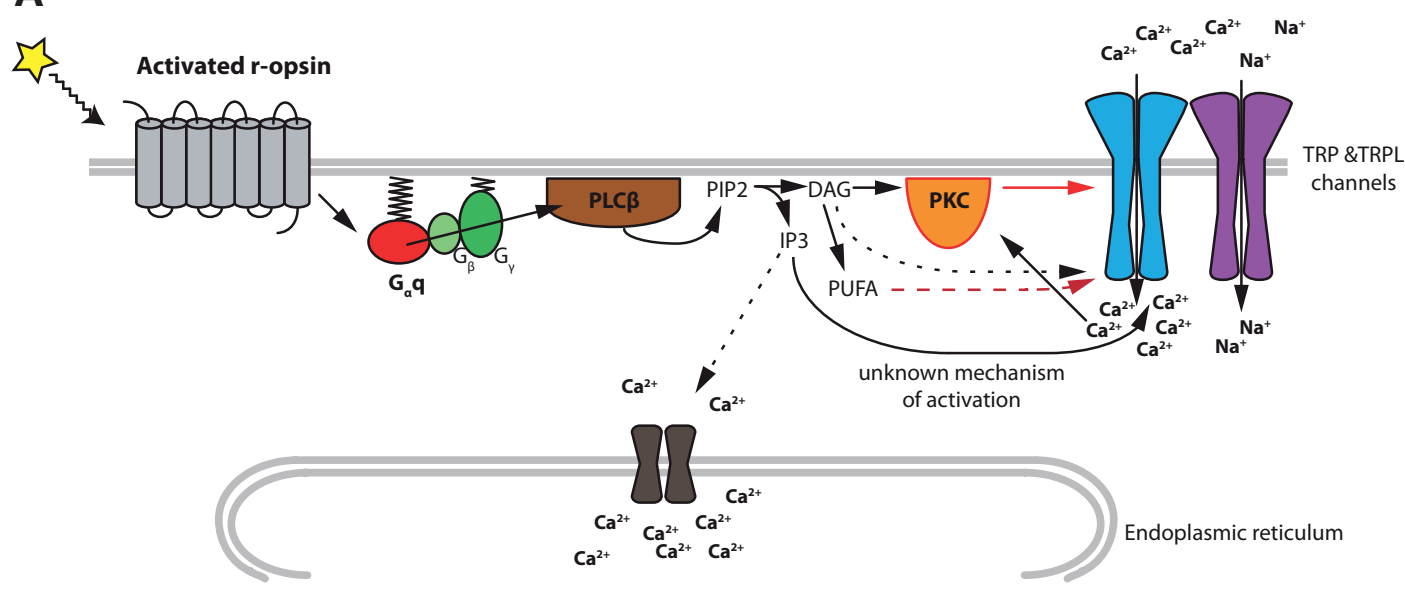

Confirmed components and interaction in both Drosophila and ipRGCs

- . - . Interactions not involved in ipRGCs

- - - Potential interactions in ipRGCs

- Analogy-based predicted interactions in ipRGCs

\section{B}

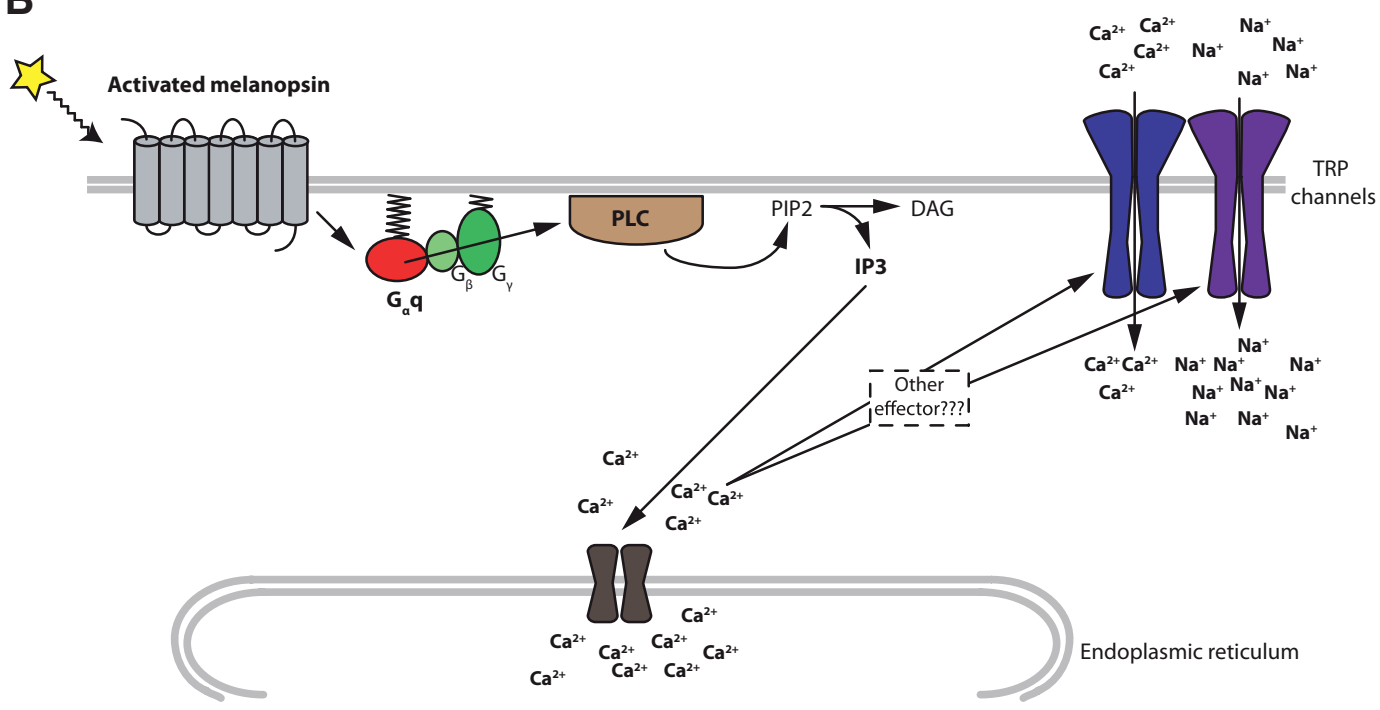

Confirmed components and interaction
Fig. 8. Phototransduction cascades in Drosophila photoreceptors, vertebrate intrinsic photosensitive ganglion cells (ipRGCs) and amphioxus dorsal ocellus (DO) and Joseph cells (JCs). Comparison of phototransduction cascades for Drosophila \& ipRGCs and amphioxus rhabdomeric photoreceptors are shown. (A) Phototransduction cascade in Drosophila retinal photoreceptors and vertebrate ipRGCs. After opsins irradiation, member of GNAQ family is activated in both of the presented cell types. Subsequently, PLCactivation was shown to be involved in both cases. Next steps in the cascade might, however, differ between Drosophila photoreceptors and ipRGCs. Some interactions identified in Drosophila photoreceptors were shown not to be involved in phototransduction in ipRGCs (marked with black dotted arrows). For ipRGCs proposed steps in the cascade are shown (marked with red arrow or red dashed arrow). (B) Phototransduction cascade in amphioxus JCs and DO. Identified components and their connections are shown. The effect of $\mathrm{Ca}^{2+}$ released from endoplasmic reticulum is still not resolved. Interestingly after the thorough studies performed in past years, the phototransduction cascade of JCs and DO is described more accurately than for Drosophila or ipRGCs. 
vertebrate ancestor, then it is clear that relatively modest modifications (loss of membrane protrusions; lower melanopsin expression; difference in phototransduction cascade) were needed to enable them attaining the lower photosensitivity necessary for their role as circadian receptors.

Taken together JCs and DO of amphioxus have a lot in common with both invertebrate rhabdomeric photoreceptors and vertebrate ipRGCs. The homology between JCs and DO and ipRGCs appears to be especially well justified. Based on the differences in their structure and development, there is, however, a possible division of roles between JCs and DO. DO seem to be more important for controlling the proper burrowing of the adult animal. Recently, noncephalic $r$-opsin positive photoreceptors along the body of the marine annelid Platynereis dumerilli were identified (Backfisch et al., 2013). When combined with data from zebrafish, where melanopsin (Opn4)-positive cells were identified in the lateral line organ, it was proposed that DO might be representative of very ancient noncephalic rhabdomeric-type photoreceptors (Backfisch et al., 2013). Additional scenario has been proposed, in which DO are evolutionarily related to vertebrate neural crest cells (Ivashkin and Adameyko, 2013). To test either of these hypotheses, more data are necessary, especially about gene expression profiles of DO. On the other hand, available data support a role of JCs as the main controllers of circadian rhythmicity in adult amphioxus, thus making them, at least functionally, more closely related to ipRGCs. Since it is difficult to find a JC homolog in other chordates and JCs are entirely restricted to amphioxus adults, one still cannot rule out the possibility that they may play a so far unknown role in amphioxus behavior. JCs might, for example, serve as shadow detectors. FE being formed by just a few photoreceptor cells seems to be used mainly in larval stage and not sufficient for the use in adults (even though it might still retain some function there). On the other hand, $\mathrm{JCs}$ are abundant in the adult, located in the anterior part projecting outside from the sand and thus exposed to ambient light. Their role might thus lie in detecting the sudden change in illumination (e.g., caused by the approaching predator) or even in monitoring the movement of the passing object (due to their expansion across the anterior body surface). Another question is the evolutionary origin of JCs, whether they are ancestral for chordates, or specific for amphioxus, which could imply the way of life of the chordates' ancestor. If the former is true, then the ancestral chordates were burrowers. Otherwise, burrowing is an innovation and ancestral chordates were Pikaia-like swimmers. Rhabdomeric photoreceptors have beenfound in the eyes of other extant chordates, salps (Gorman et al., 1971; McReynolds and Gorman, 1975). Recently, an analysis of the brain and eyes of salp Thalia democratica was performed (Braun and Stach, 2017). It was documented that T. democratica eyes are positioned in the brain region that might be homologous to amphioxus CV (with its Di-Mesencephalic characteristics). It is not clear whether salp's eyes are homologous to JCs or not. If so, they would probably represent ancestral chordate photosensitive organs, or at least an example of the chordate's potential to make rhabdomeric receptors from the dorsal midbrain (necessary for various tasks). In this case, the lamellate cells (whose number in the adult stays the same as in larva's compact LB) might then still be active in the regulation of circadian rhythm in adults.

\section{Conclusion}

Here, we have reviewed available information on photoreception in amphioxus. Starting with general observations on light-guided behavior of the animals we examined subjects as diverse as anatomy, morphology, physiology, gene expression profiles and molecular pathways underlying photoreception, in the four distinct photoreceptive organs of amphioxus, namely the FE, LB, DO and JCs. We were especially concerned with possible homologies of amphioxus photoreceptive organs to their vertebrate counterparts. The possible role put forward for amphioxus photoreceptive organs is summarized in Table 2. However, when looking more closely at the proposed homologies, it is becoming clear that more experimental data is desirable to strengthen them. The proposed homology between amphioxus FE and vertebrate lateral eyes stands on solid grounds, being based so far on the FE gene expression fingerprint and EM analysis. Data about the physiology of FE photoreceptors, the phototransduction cascade they utilize, and their development are, however, missing. In addition, information about the FE connectome (projecting neurons) is needed. The homology between the LB and the vertebrate pineal gland is mainly based on the striking morphological similarity between their photoreceptors and location of the LB at the dorsal part of the CV. To corroborate such homology,

TABLE 2

\section{OVERVIEW OF PUTATIVE FUNCTION AND PROPOSED HOMOLOGY FOR PARTICULAR AMPHIOXUS PHOTORECEPTIVE ORGANS}

\begin{tabular}{|c|c|c|c|}
\hline Photoreceptive organ & Putative function & Proposed homology & References \\
\hline \multirow[t]{2}{*}{ Frontal eye } & $\begin{array}{l}\text { Orientation of larvae while hovering in water } \\
\text { column during feeding }\end{array}$ & & Stokes and Holland, 1995 \\
\hline & & Vertebrate lateral eyes & $\begin{array}{l}\text { Kemna, 1904; Lacalli et al., 1994; } \\
\text { Vopalensky et al., } 2012\end{array}$ \\
\hline \multirow[t]{2}{*}{ Lamellar body } & Circadian rhythmicity (in larva and/or adult) & & Wicht and Lacalli, 2005; This study \\
\hline & & Vertebrate pineal organ & Eakin, 1968; Ruiz and Anadon, 1991b \\
\hline \multirow[t]{4}{*}{ Joseph cells } & Circadian rhythmicity (in adult) & & This study \\
\hline & Changes in ambient light intensity & & This study \\
\hline & & Vertebrate ipRGCs & Koyanagi et al., 2005; Gomez et al., 2009 \\
\hline & & Ancestral chordate cerebral rhabdomeric photoreceptors & This study \\
\hline \multirow[t]{6}{*}{ Dorsal ocelli } & Negative phototaxis of adults & & Hesse, 1898; Parker, 1908; Guthrie, 1975 \\
\hline & Regulation of larval swimming modes $\left(1^{\text {st }} \mathrm{DO}\right)$ & & Lacalli, 2002 \\
\hline & Adjusting height in the sand burrow & & Lacalli, 2004 \\
\hline & & Vertebrate ipRGCs & Koyanagi et al., 2005; Gomez et al., 2009 \\
\hline & & Ancestral bilaterian non-cephalic rhabdomeric type photoreceptors & Backfisch et al., 2013; This study \\
\hline & & Neural crest cells of vertebrates (neuroepithelial progenitors of the DOs) & Ivashkin and Adameyko, 2013 \\
\hline
\end{tabular}


additional data about LB development, physiology and especially gene expression will be needed. It is considerably more difficult to ascribe vertebrate homology to JCs and DO. Homology of amphioxus JCs to ipRGCs, especially to the population of ipRGCs involved in circadian rhythm control, seems modestly supported on the basis of $\mathrm{JC}$ physiology and the lack of closely associated pigment. It is likely that they function as non-directional photoreceptors, possibly involved in controlling the circadian rhythm in adult amphioxus. We put forward hypotheses proposing homologies of the DO to three vertebrate systems: ipRGCs, melanopsin-positive lateral line cells, and neural crest cells, respectively. We anticipate that future work will allow us to discriminate amongst these scenarios.

In conclusion, the four classes of amphioxus photoreceptive organs represent an exciting model for evolutionary studies. They not only serve as a window into the ancestral chordate condition but also provide an insight into the evolution of vertebrate photoreception.

\section{Acknowledgement}

This work was funded by the Czech Science Foundation (17-15374S). We acknowledge the Microscopy Centre - Light Microscopy Core Facility, IMG ASCR, Prague, Czech Republic, supported by grants (CzechBioimaging - MEYS LM2015062), "Centre of Model Organisms" OPPK (CZ.2.16/3.1.00/21547) and "Biomodels for health" (LO1419), for their support with the confocal imaging presented herein.

We are grateful to Nicholas D. Holland, Trevor D. Lamb, Dan-Eric Nilsson and Thurston Lacalli for their insightful comments and suggestions on the earlier version of this manuscript.

\section{References}

ACEMEL, R.D., TENA, J.J., IRASTORZA-AZCARATE, I., MARLETAZ, F., GOMEZMARIN, C., DE LACALLE-MUSTIENES, E., BERTRAND, S., DIAZ, S.G., ALDEA, D., AURY, J.M. et al., (2016). A single three-dimensional chromatin compartment in amphioxus indicates a stepwise evolution of vertebrate Hox bimodal regulation. Nat Genet 48: 336-341.

ALBUIXECH-CRESPO, B., LOPEZ-BLANCH, L., BURGUERA, D., MAESO, I., SANCHEZ-ARRONES, L., MORENO-BRAVO, J.A., SOMORJAI, I., PASCUALANAYA, J., PUELLES, E., BOVOLENTA, P. et al., (2017). Molecular regionalization of the developing amphioxus neural tube challenges major partitions of the vertebrate brain. PLOS Biol 15: e2001573.

ANGUEYRA, J.M., PULIDO, C., MALAGON, G., NASI, E. and GOMEZ MDEL, P. (2012). Melanopsin-expressing amphioxus photoreceptors transduce light via a phospholipase C signaling cascade. PLoS One 7: e29813.

ARENDT, D., TESSMAR-RAIBLE, K., SNYMAN, H., DORRESTEIJN, A.W. and WITTBRODT, J. (2004). Ciliary photoreceptors with a vertebrate-type opsin in an invertebrate brain. Science 306: 869-871.

ARIKAWA, K., KAWAMATA, K., SUZUKI, T. and EGUCHI, E. (1987). Daily changes of structure, function and rhodopsin content in the compound eye of the crab Hemigrapsus sanguineus. J Comp Physiol A 161: 161-174.

ARIKAWA, K., MORIKAWA, Y., SUZUKI, T. and EGUCHI, E. (1988). Intrinsic control of rhabdom size and rhodopsin content in the crab compound eye by a circadian biological clock. Experientia 44: 219-220.

BACKFISCH, B., VEEDIN RAJAN, V.B., FISCHER, R.M., LOHS, C., ARBOLEDA, E., TESSMAR-RAIBLE, K. and RAIBLE, F. (2013). Stable transgenesis in the marine annelid Platynereis dumerilii sheds new light on photoreceptor evolution. Proc Natl Acad Sci USA 110: 193-198.

BAILES, H.J. and LUCAS, R.J. (2013). Human melanopsin forms a pigment maximally sensitive to blue light (lambdamax approximately $479 \mathrm{~nm}$ ) supporting activation of $\mathrm{G}(\mathrm{q} / 11)$ and $\mathrm{G}(\mathrm{i} / \mathrm{o})$ signalling cascades. Proc Biol Sci 280: 20122987.

BARDET, P.L., SCHUBERT, M., HORARD, B., HOLLAND, L.Z., LAUDET, V., HOLLAND, N.D. and VANACKER, J.M. (2005). Expression of estrogen-receptor related receptors in amphioxus and zebrafish: implications for the evolution of posterior brain segmentation at the invertebrate-to-vertebrate transition. EvolDev7:223-233.

BASSETT, E.A. and WALLACE, V.A. (2012). Cell fate determination in the vertebrate retina. Trends Neurosci 35: 565-573.

BERTRAND, S. and ESCRIVA, H. (2011). Evolutionary crossroads in developmental biology: amphioxus. Development 138: 4819-4830.

BISCONTIN, A., FRIGATO, E., SALES, G., MAZZOTTA, G.M., TESCHKE, M., DE PITTA, C., JARMAN, S., MEYER, B., COSTA, R. and BERTOLUCCI, C. (2016). The opsin repertoire of the Antarctic krill Euphausia superba. Mar Genomics 29:61-68.

BOVERI, T. (1904). Ueber die phylogenetische Bedeutung der Sehorgane des Amphioxus. Zool. Jahrb. Supplement 7: 409-428.

BOWMAKER, J.K. and WAGNER, H.J. (2004). Pineal organs of deep-sea fish photopigments and structure. J Exp Biol 207: 2379-2387.

BOZZO, M., MACRI, S., CALZIA, D., SGARRA, R., MANFIOLETTI, G., RAMOINO, P., LACALLI, T., VIGNALI, R., PESTARINO, M. and CANDIANI, S. (2017). The HMGA gene family in chordates: evolutionary perspectives from amphioxus. Dev Genes Evol 227: 201-211

BRAUN, K. and STACH, T. (2017). Structure and ultrastructure of eyes and brains of Thalia democratica (Thaliacea, Tunicata, Chordata). J Morphol. 278:1421-1437. (doi: 10.1002/jmor.20722).

BROWN, J.E., RUBIN, L.J., GHALAYINI, A.J., TARVER, A.P., IRVINE, R.F., BERRIDGE, M.J. and ANDERSON, R.E. (1984). myo-Inositol polyphosphate may be a messenger for visual excitation in Limulus photoreceptors. Nature 311: 160-163.

CAMERON, E.G. and ROBINSON, P.R. (2014). beta-Arrestin-dependent deactivation of mouse melanopsin. PLoS One 9: e113138.

CANDIANI, S., MORONTI, L., RAMOINO, P., SCHUBERT, M. and PESTARINO, M. (2012). A neurochemical map of the developing amphioxus nervous system. BMC Neurosci 13: 59.

CASTRO, A., BECERRA, M., MANSO, M.J. and ANADON, R. (2015). Neuronal Organization of the Brain in the Adult Amphioxus (Branchiostoma lanceolatum): AStudy With Acetylated Tubulin Immunohistochemistry. J Comp Neurol 523: 2211-2232.

CASTRO, A., BECERRA, M., MANSO, M.J., SHERWOOD, N.M. and ANADON, R (2006). Anatomy of the Hesse photoreceptor cell axonal system in the central nervous system of amphioxus. J Comp Neurol 494: 54-62.

CHIN, T.G. (1941). Studies on the Biology of the Amoy Amphioxus Branchiostoma belcheri Gray. Philippine J. Science 75: 369-421.

CHYB, S., RAGHU, P. and HARDIE, R.C. (1999). Polyunsaturated fatty acids activate the Drosophila light-sensitive channels TRP and TRPL. Nature 397: 255-259.

CONNAUGHTON, V. (2005). Glutamate and Glutamate Receptors in the Vertebrate Retina. Kolb H, Fernandez E, Nelson R, editors. Webvision: The Organization of the Retina and Visual System [Internet]. Salt Lake City (UT): University of Utah Health Sciences Center; 1995-. Available from: https://www.ncbi.nlm.nih.gov/ books/NBK11526/ (updated 2007).

COSTA, G. (1834). Annuario zoologico. Cenni Zoologici ossia descrizione sommaria delle specie nuove di animali discoperti in diverse contrade del regno nell' anno 1834 (cited from Willey 1894). Azzolino, Napoli.

CROZIER, W.J. (1917). The photoreceptors of amphioxus. Contrib. Bermuda Biol. Stn. Res. (reprinted from Anat Rec vol. 11, 1916) 4: 3.

DARWIN, C. (1859). On the Origin of Species by Means of Natural Selection, or the Preservation of Favoured Races in the Struggle for Life. John Murray, London.

DAVIS, T.L. and REBAY, I. (2017). Master regulators in development: Views from the Drosophila retinal determination and mammalian pluripotency gene networks. Dev Biol 421: 93-107.

DEL PILAR GOMEZ, M. and NASI, E. (1998). Membrane current induced by protein kinase $\mathrm{C}$ activators in rhabdomeric photoreceptors: implications for visual excitation. J Neurosci 18: 5253-5263.

DELGADO, R., MUNOZ, Y., PENA-CORTES, H., GIAVALISCO, P. and BACIGALUPO, J. (2014). Diacylglycerol activates the light-dependent channel TRP in the photosensitive microvilli of Drosophila melanogaster photoreceptors. J Neurosci 34: 6679-6686.

DO, M.T. and YAU, K.W. (2015). Intrinsically Photosensitive Retinal Ganglion Cells. Physiol Rev. 90: 1547-1581.

EAKIN, R.M. and WESTFALL, J.A. (1962a). Fine structure of photoreceptors in Amphioxus. J Ultrastruct Res 6: 531-539.

EAKIN, R.M. and WESTFALL, J.A. (1962b). Fine Structure of Photoreceptors in the Hydromedusan, Polyorchis Penicillatus. Proc Natl Acad Sci USA 48: 826-833.

FEIN, A., PAYNE, R., CORSON, D.W., BERRIDGE, M.J. and IRVINE, R.F. (1984) Photoreceptor excitation and adaptation by inositol 1,4,5-trisphosphate. Nature 
311: 157-160.

FERRER, C., MALAGON, G., GOMEZ MDEL, P. and NASI, E. (2012). Dissecting the determinants of light sensitivity in amphioxus microvillar photoreceptors: possible evolutionary implications for melanopsin signaling. J Neurosci 32: 17977-17987.

FEUDA, R., ROTA-STABELLI, O., OAKLEY, T.H. and PISANI, D. (2014). The Comb Jelly Opsins and the Origins of Animal Phototrasduction. Genome Biol Evol6: 1964-1971.

FRANZ, V. (1923). Haur, Sinnesorgane und Nervensystem der Akranier. Z Naturwiss 13: 401-526.

FUENTES, M., BENITO, E., BERTRAND, S., PARIS, M., MIGNARDOT, A., GODOY, L., JIMENEZ-DELGADO, S., OLIVERI, D., CANDIANI, S., HIRSINGER, E. et al., (2007). Insights into spawning behavior and development of the European amphioxus (Branchiostoma lanceolatum). J Exp Zool B Mol Dev Evol 308: 484-493.

GLARDON, S., HOLLAND, L.Z., GEHRING, W.J. and HOLLAND, N.D. (1998). Isolation and developmental expression of the amphioxus Pax-6 gene (AmphiPax-6): insights into eye and photoreceptor evolution. Development 125: 2701-2710.

GOMEZ MDEL, P., ANGUEYRA, J.M. and NASI, E. (2009). Light-transduction in melanopsin-expressing photoreceptors of Amphioxus. Proc Natl Acad Sci USA 106: 9081-9086.

GONG, J., YUAN, Y., WARD, A., KANG, L., ZHANG, B., WU, Z., PENG, J., FENG, Z., LIU, J. and XU, X.Z. (2016). The C. elegans Taste Receptor Homolog LITE-1 Is a Photoreceptor. Cell 167: 1252-1263 e1210.

GORMAN, A.L., MCREYNOLDS, J.S. and BARNES, S.N. (1971). Photoreceptors in primitive chordates: fine structure, hyperpolarizing receptor potentials, and evolution. Science 172: 1052-1054

GRAHAM, D.M., WONG, K.Y., SHAPIRO, P., FREDERICK, C., PATTABIRAMAN, K. and BERSON, D.M. (2008). Melanopsin ganglion cells use a membrane-associated rhabdomeric phototransduction cascade. J Neurophysiol 99: 2522-2532.

GUTHRIE, D.M. (1975). The Physiology and Structure of the Nervous System of Amphioxus (the Lancelet) Branchiostoma Lanceolatum Pallas. Symp Zool Soc Lond (Protochordates) 36: 43-80.

HARDIE, R.C. and FRANZE, K. (2012). Photomechanical responses in Drosophila photoreceptors. Science 338: 260-263.

HARIYAMA, T., MEYER-ROCHOW, V.B., KAWAUCHI, T., TAKAKU, Y. and TSUKAHARA, Y. (2001). Diurnal changes in retinula cell sensitivities and receptive fields (two-dimensional angular sensitivity functions) in the apposition eyes of Ligia exotica (Crustacea, Isopoda). J Exp Biol 204: 239-248.

HAUG, M.F., GESEMANN, M., LAZOVIC, V. and NEUHAUSS, S.C. (2015). Eumetazoan cryptochrome phylogeny and evolution. Genome Biol Evol 7: 601-619.

HESSE, R. (1898). Untersuchungen über die Organe der Lichtempfindung bei niederen Thieren. IV. Die sehorgane des Amphioxus. Z Wiss Zool 63: 456-464.

HOLLAND, L.Z. (2017). Invertebrate Origins of Vertebrate Nervous Systems.

HOLLAND, L.Z., ALBALAT, R., AZUMI, K., BENITO-GUTIERREZ, E., BLOW, M.J., BRONNER-FRASER, M., BRUNET, F., BUTTS, T., CANDIANI, S., DISHAW, L.J. et al., (2008). The amphioxus genome illuminates vertebrate origins and cephalochordate biology. Genome Res 18: 1100-1111.

HOLLAND, L.Z. and YU, J.K. (2004). Cephalochordate (amphioxus) embryos: procurement, culture, and basic methods. Methods Cell Biol 74: 195-215.

HOLLAND, N.D. (2011). Spawning periodicity of the lancelet, Asymmetron lucayanum (Cephalochordata), in Bihimi, Bahamas. Ital J Zool 78: 478-486.

HOLLAND, N.D. and HOLLAND, L.Z. (2010). Laboratory spawning and development of the Bahama lancelet, Asymmetron lucayanum (cephalochordata): fertilization through feeding larvae. Biol Bull 219: 132-141.

HUANG, J., LIU, C.H., HUGHES, S.A., POSTMA, M., SCHWIENING, C.J. and HARDIE, R.C. (2010). Activation of TRP channels by protons and phosphoinositide depletion in Drosophila photoreceptors. Curr Biol 20: 189-197.

HUGHES, S., HANKINS, M.W., FOSTER, R.G. and PEIRSON, S.N. (2012). Melanopsin phototransduction: slowly emerging from the dark. Prog Brain Res 199: 19-40.

IVASHKIN, E. and ADAMEYKO, I. (2013). Progenitors of the protochordate ocellus as an evolutionary origin of the neural crest. Evodevo 4: 12.

JELGERSMA, G. (1906). DerUrsprung des Wilbeltierauges. Morphol. Jahrb. 35:377-394.

JOSEPH, H. (1904). Über eigentümliche Zellstrukturen im Zentralnervensystem von Amphioxus. Verh Anat Ges. Ergänzungsh. z. Bd. 25: 16-26.

KEMNA, A. (1904). Les structures cerebrales dorsales chez les vertebres inferieurs. Ann. Soc. R. Zool. Belg. 39: 196-201.
KOHL, C. (1890). Einige Bemerkungen über Sinnesorgane desAmphioxus lanceolatus. Zoologischer Anzeiger 13: 182-185.

KOJIMA, K., YAMASHITA, T., IMAMOTO, Y., KUSAKABE, T.G., TSUDA, M. and SHICHIDA, Y. (2017). Evolutionary steps involving counterion displacement in a tunicate opsin. Proc Natl Acad Sci USA 114: 6028-6033.

KOLB, H. (2011). Neurotransmitters in the Retina by Helga Kolb. Kolb H, Fernandez E, Nelson R, editors. Webvision: The Organization of the Retina and Visual System [Internet]. Salt Lake City (UT): University of Utah Health Sciences Center; 1995Available from: http://webvision.med.utah.edu/book/part-iv-neurotransmitters-inthe-retina-2/part-iv-neurotransmitters-in-the-retinal (updated 2011).

KOYANAGI, M., KUBOKAWA, K., TSUKAMOTO, H., SHICHIDA, Y. and TERAKITA, A (2005). Cephalochordate melanopsin: evolutionary linkage between invertebrate visual cells and vertebrate photosensitive retinal ganglion cells. Curr Bio/15: 1065-1069.

KOYANAGI, M., TERAKITA, A., KUBOKAWA, K. and SHICHIDA, Y. (2002). Amphioxus homologs of Go-coupled rhodopsin and peropsin having 11-cis-and all-trans-retinals as their chromophores. FEBS Lett 531: 525-528.

KOZMIK, Z. (2008). The role of Pax genes in eye evolution. Brain Res Bull 75: 335-339.

KOZMIK, Z., HOLLAND, N.D., KALOUSOVA, A., PACES, J., SCHUBERT, M. and HOLLAND, L.Z. (1999). Characterization of an amphioxus paired box gene, AmphiPax2/5/8: developmental expression patterns in optic support cells, nephridium, thyroid-like structures and pharyngeal gill slits, but not in the midbrain-hindbrain boundary region. Development 126: 1295-1304.

KOZMIK, Z., HOLLAND, N.D., KRESLOVA, J., OLIVERI, D., SCHUBERT, M., JONASOVA, K., HOLLAND, L.Z., PESTARINO, M., BENES, V. and CANDIANI, S. (2007) Pax-Six-Eya-Dach network during amphioxus development: conservation in vitro but context specificity in vivo. Dev Biol 306: 143-159.

KRAUSE, W. (1888). Die Retina. II. Die Retina der Fische. Int Monatssch Anat Physiol 5: $132-148$.

KUME, K., ZYLKA, M.J., SRIRAM, S., SHEARMAN, L.P., WEAVER, D.R., JIN, X. MAYWOOD, E.S., HASTINGS, M.H. and REPPERT, S.M. (1999). mCRY1 and mCRY2 are essential components of the negative limb of the circadian clock feedback loop. Cell 98: 193-205.

KUTTA, R.J., ARCHIPOWA, N., JOHANNISSEN, L.O., JONES, A.R. and SCRUTTON N.S. (2017). Vertebrate Cryptochromes are Vestigial Flavoproteins. Sci Rep7:44906

LACALLI, T. and CANDIANI, S. (2017). Locomotory control in amphioxus larvae: new insights from neurotransmitter data. Evodevo 8: 4.

LACALLI, T.C. (1996). Frontal eye circuitry, rostral sensory pathways and brain organization in amphioxus larvae: evidence from 3D reconstructions. Philos. Trans. Royal Soc. B: Biol. Sci. 351: 243-263.

LACALLI, T.C. (2002). The dorsal compartment locomotory control system in amphioxus larvae. J Morphol 252: 227-237.

LACALLI, T.C. (2004). Sensory systems in amphioxus: a window on the ancestral chordate condition. Brain Behav Evol 64: 148-162.

LACALLI, T.C. (2008). Basic features of the ancestral chordate brain: a protochordate perspective. Brain Res Bull 75: 319-323.

LACALLI, T.C. and KELLY, S.J. (2003). Ventral neurons in the anterior nerve cord of amphioxus larvae. I. An inventory of cell types and synaptic patterns. J Morphol 257: 190-211.

LACALLI., T.C., HOLLAND., N.D. and WEST, J.E. (1994). Landmarks in the Anterior Central Nervous System of Amphioxus Larvae. Phil Trans Roy Soc B Biol Sci 344: 165-185.

LAMB, T.D. (2013). Evolution of phototransduction, vertebrate photoreceptors and retina. Prog Retin Eye Res 36: 52-119.

LAMB, T.D., COLLIN, S.P. and PUGH, E.N., JR. (2007). Evolution of the vertebrate eye: opsins, photoreceptors, retina and eye cup. Nat Rev Neurosci 8: 960-976.

LAMB, T.D. and HUNT, D.M. (2017). Evolution of the vertebrate phototransduction cascade activation steps. Dev Biol. 431: 77-92.

LAMB, T.D., PATEL, H., CHUAH, A., NATOLI, R.C., DAVIES, W.I., HART, N.S., COLLIN S.P. and HUNT, D.M. (2016). Evolution of Vertebrate Phototransduction: Cascade Activation. Mol Biol Evol 33: 2064-2087.

LARHAMMAR, D., NORDSTROM, K. and LARSSON, T.A. (2009). Evolution of vertebrate rod and cone phototransduction genes. Phil Trans Roy Soc Lond B Biol Sci 364: 2867-2880.

LAWRENCE, P.A. and KRASNE, F.B. (1965). Annelid Ciliary Photoreceptors. Science 
148: $965-966$.

LI, G., SHU, Z. and WANG, Y. (2013). Year-Round Reproduction and Induced Spawning of Chinese Amphioxus, Branchiostoma belcheri, in Laboratory. PLoS One e75461.

LIEB, W.E., SMITH-LANG, L., DUA, H.S., CHRISTENSEN, A.C. and DONOSO, L.A. (1991). Identification of an S-antigen-like molecule in Drosophila melanogaster: an immunohistochemical study. Exp Eye Res 53: 171-178.

LIEGERTOVA, M., PERGNER, J., KOZMIKOVA, I., FABIAN, P., POMBINHO, A.R., STRNAD, H., PACES, J., VLCEK, C., BARTUNEK, P. and KOZMIK, Z. (2015). Cubozoan genome illuminates functional diversification of opsins and photoreceptor evolution. Sci Rep 5: 11885

MARIN, E.P., KRISHNA, A.G., ZVYAGA, T.A., ISELE, J., SIEBERT, F. and SAKMAR, T.P. (2000). The amino terminus of the fourth cytoplasmic loop of rhodopsin modulates rhodopsin-transducin interaction. J Biol Chem 275: 1930-1936.

MCREYNOLDS, J.S. and GORMAN, A.L. (1975). Hyperpolarizing photoreceptors in the eye of a primitive chordate, Salpa democratica. Vision Res 15: 1181-1186.

MEVES,A. (1973). Elektronmikroskopische Untersuchungenüber die Zytoarchitektur des Gehirns von Branchiostoma lanceolatum. Z Zellforsch Mikrosk Anat 139: 511-532.

MIRSHAHI, M., BOUCHEIX, C., COLLENOT, G., THILLAYE, B. and FAURE, J.P. (1985). Retinal S-antigen epitopes in vertebrate and invertebrate photoreceptors. Invest Ophthalmol Vis Sci 26: 1016-1021.

MULLER, W.E., SCHRODER, H.C., MARKL, J.S., GREBENJUK, V.A., KORZHEV, M., STEFFEN, R. and WANG, X. (2013). Cryptochrome in sponges: a key molecule linking photoreception with phototransduction. J Histochem Cytochem 61:814-832.

NAGEL, W.A. (1896). Der Lichtsinn augenloser Thiere. Eine biologische Studie. Fischer, Jena.

NAKAO, T. (1964). On the Fine Structure of the Amphioxus Photoreceptor. Tohoku J Exp Med 82: 349-363.

NASI, E. and DEL PILAR GOMEZ, M. (2009). Melanopsin-mediated light-sensing in amphioxus: a glimpse of the microvillar photoreceptor lineage within the deuterostomia. Commun Integr Biol 2: 441-443.

NILSSON, D.E. (2013). Eye evolution and its functional basis. Vis Neurosci 30: 5-20.

PANTZARTZI, C.P., PERGNER, J., KOZMIKOVA, I. and KOZMIK, Z. (2017). The opsin repertoire of the European lancelet: a window into light detection in a basal chordate. Int J Dev Biol (accepted).

PARKER, G.H. (1908). The Sensory Reactions of Amphioxus. Proc Amer Acad Arts Sci 43: 415-455.

PAYNE, R., CORSON, D.W. and FEIN, A. (1986). Pressure injection of calcium both excites and adapts Limulus ventral photoreceptors. J Gen Physiol 88: 107-126.

PEINADO, G., OSORNO, T., GOMEZ MDEL, P. and NASI, E. (2015). Calcium activates the light-dependent conductance in melanopsin-expressing photoreceptors of amphioxus. Proc Natl Acad Sci USA 112: 7845-7850.

PFISTER, C., CHABRE, M., PLOUET, J., TUYEN, V.V., DE KOZAK, Y., FAURE, J.P. and KUHN, H. (1985). Retinal $S$ antigen identified as the $48 \mathrm{~K}$ protein regulating light-dependent phosphodiesterase in rods. Science 228: 891-893.

PLACHETZKI, D.C., DEGNAN, B.M. and OAKLEY, T.H. (2007). The origins of novel protein interactions during animal opsin evolution. PLOS One 2: e1054.

PORTER, M.L., BLASIC, J.R., BOK, M.J., CAMERON, E.G., PRINGLE, T., CRONIN, T.W. and ROBINSON, P.R. (2012). Shedding new light on opsin evolution. Proc Biol Sci 279: 3-14

PROVENCIO, I., JIANG, G., DE GRIP, W.J., HAYES, W.P. and ROLLAG, M.D. (1998). Melanopsin: An opsin in melanophores, brain, and eye. Proc Natl Acad Sci USA 95: 340-345.

PULIDO, C., MALAGON, G., FERRER, C., CHEN, J.K., ANGUEYRA, J.M., NASI, E. and GOMEZMDEL, P. (2012). The light-sensitive conductance of melanopsin-expressing Joseph and Hesse cells in amphioxus. J Gen Physiol 139: 19-30.

RAMIREZ, M.D., PAIRETT, A.N., PANKEY, M.S., SERB, J.M., SPEISER, D.I., SWAFFORD, A.J. and OAKLEY, T.H. (2016). The Last Common Ancestor of Most Bilaterian Animals Possessed at Least Nine Opsins. Genome Biol Evol 8: 3640-3652.

RIVERA, A.S., OZTURK, N., FAHEY, B., PLACHETZKI, D.C., DEGNAN, B.M., SANCAR, A. and OAKLEY, T.H. (2012). Blue-light-receptive cryptochrome is expressed in a sponge eye lacking neurons and opsin. J Exp Biol 215: 1278-1286.

RUIZ, M.S. and ANADON, R. (1991a). Some considerations on the fine structure of rhabdomeric photoreceptors in the amphioxus, Branchiostoma lanceolatum (Cephalochordata). J Hirnforsch 32: 159-164.
RUIZ, S. and ANADON, R. (1991b). The fine structure of lamellate cells in the brain of amphioxus (Branchiostoma lanceolatum, Cephalochordata). Cell Tiss Res 263: 597-600.

SAKURA, M., TAKASUGA, K., WATANABE, M. and EGUCHI, E. (2003). Diurnal and circadian rhythm in compound eye of cricket (Gryllus bimaculatus): changes in structure and photon capture efficiency. Zoolog Sci 20: 833-840.

SAND, A., SCHMIDT, T.M. and KOFUJI, P. (2012). Diverse types of ganglion cell photoreceptors in the mammalian retina. Prog Retin Eye Res 31: 287-302.

SATIR, P. and CHRISTENSEN, S.T. (2008). Structure and function of mammalian cilia Histochem Cell Biol 129: 687-693.

SCHOMERUS, C., KORF, H.-W., LAEDTKE, E., MORET, F., ZHANG, Q. and WICHT, H. (2008). Nocturnal Behavior and Rhythmic Period Gene Expression in a Lancelet, Branchiostoma lanceolatum. J Bio Rhyth 23: 170-181.

SERGEEV, B.F. (1963). The sensory reactions of Amphioxus and the effects of anesthesia (In Russian). Fiziol. Zh. SSSR (cited in Guthrie, 1975) 49: 60-65.

SHEARMAN, L.P., SRIRAM, S., WEAVER, D.R., MAYWOOD, E.S., CHAVES, I. ZHENG, B., KUME, K., LEE, C.C., VAN DER HORST, G.T., HASTINGS, M.H. et al., (2000). Interacting molecular loops in the mammalian circadian clock. Science 288: 1013-1019.

STOKES, M.D. and HOLLAND, N.D. (1995). Ciliary Hovering in Larval Lancelets (=Amphioxus). Biol Bull 188: 231-233

SUZUKI, D.G., MURAKAMI, Y., ESCRIVA, H. and WADA, H. (2015). A comparative examination of neural circuit and brain patterning between the lamprey and amphioxus reveals the evolutionary origin of the vertebrate visual center. J Comp Neurol 523: 251-261.

SWAROOP, A., KIM, D. and FORREST, D. (2010). Transcriptional regulation of photoreceptor development and homeostasis in the mammalian retina. Nat Rev Neurosci 11: 563-576.

TERAKITA, A. (2005). The opsins. Genome Biol 6: 213.

TERAKITA, A., KAWANO-YAMASHITA, E. and KOYANAGI, M. (2012). Evolution and diversity of opsins.. Memb Transp Signal 1: 104-111.

TERAKITA, A., KOYANAGI, M., TSUKAMOTO, H., YAMASHITA, T., MIYATA, T. and SHICHIDA, Y. (2004). Counterion displacement in the molecular evolution of the rhodopsin family. Nat Struct Mol Biol 11: 284-289.

TERAKITA, A., TSUKAMOTO, H., KOYANAGI, M., SUGAHARA, M., YAMASHITA, T and SHICHIDA, Y. (2008). Expression and comparative characterization of Gqcoupled invertebrate visual pigments and melanopsin. J Neurochem 105: 883-890.

TSUKAMOTO, H., TERAKITA, A. and SHICHIDA, Y. (2005). A rhodopsin exhibiting binding ability to agonist all-trans-retinal. Proc Natl Acad Sci USA 102: 6303-6308.

VAN DER SCHALIE, E. and GREEN, C.B. (2005). Cryptochromes. Curr Biol 15: R785.

VAN VEEN, T., ELOFSSON, R., HARTWIG, H.G., GERY, I., MOCHIZUKI, M., CENA V. and KLEIN, D.C. (1986). Retinal S-antigen: immunocytochemical and immunochemical studies on distribution in animal photoreceptors and pineal organs. Exp Biol 45: 15-25.

VOPALENSKY, P., PERGNER, J., LIEGERTOVA, M., BENITO-GUTIERREZ, E., ARENDT, D. and KOZMIK, Z. (2012). Molecular analysis of the amphioxus frontal eye unravels the evolutionary origin of the retina and pigment cells of the vertebrate eye. Proc Natl Acad Sci USA 109: 15383-15388.

WATANABE, T. and YOSHIDA, M. (1986). Morphological and histochemical studies on Joseph cells of amphioxus, Branchiostoma belcheri Gray. Exp Biol 46: 67-73.

WEBB, J.E. (1969). On the feeding and behavior of the larva of Branchiostoma lanceolatum. Marine Biol. 3: 58-72.

WELSCH, U. (1968). [The ultrastructure of the cells of Joseph in the brain of Amphioxus] Z Zellforsch Mikrosk Anat 86: 252-261.

WICHT, H. and LACALLI, T.C. (2005). The nervous system of amphioxus: structure, development and evolutionary significance. Canadian J. Zool. 83: 122-150.

WICKSTEAD, J.H. and BONE, Q. (1959). Ecology of Acraniate Larvae. Nature 184 1849-1851.

WILLEY,A. (1894). Amphioxus and the Ancestry of the Vertebrates. Macmillan, New York. WILLIAMS, N.A. and HOLLAND, P.W.H. (1996). Old head on young shoulders. Nature 383.

YU, J.K., MEULEMANS, D., MCKEOWN, S.J. and BRONNER-FRASER, M. (2008) Insights from the amphioxus genome on the origin of vertebrate neural crest. Genome Res 18: 1127-1132. 


\section{Further Related Reading, published previously in the Int. J. Dev. Biol.}

From the American to the European amphioxus: towards experimental Evo-Devo at the origin of chordates Jordi Garcia-Fernàndez, Senda Jiménez-Delgado, Juan Pascual-Anaya, Ignacio Maeso, Manuel Irimia, Carolina Minguillón, Èlia BenitoGutiérrez, Josep Gardenyes, Stéphanie Bertrand and Salvatore D’Aniello

Int. J. Dev. Biol. (2009) 53: 1359-1366

https://doi.org/10.1387/ijdb.072436jg

Evolution of CUT class homeobox genes: insights from the genome of the amphioxus, Branchiostoma floridae Naohito Takatori and Hidetoshi Saiga

Int. J. Dev. Biol. (2008) 52: 969-977

https://doi.org/10.1387/ijdb.072541nt

Peter Holland, homeobox genes and the developmental basis of animal diversity

Sebastian M. Shimeld

Int. J. Dev. Biol. (2008) 52: 3-7

https://doi.org/10.1387/ijdb.072394ss

Developmental expression of the High Mobility Group B gene in the amphioxus, Branchiostoma belcheri tsingtauense

Xiangwei Huang, Lifeng Wang and Hongwei Zhang

Int. J. Dev. Biol. (2005) 49: 49-46

http://www.intjdevbiol.com/web/paper/041915xh

Cell morphology in amphioxus nerve cord may reflect the time course of cell differentiation T C Lacalli

Int. J. Dev. Biol. (2000) 44: 903-906

http://www.intjdevbiol.com/web/paper/11206331

Embryonic development of heads, skeletons and amphioxus: Edwin S. Goodrich revisited P W Holland

Int. J. Dev. Biol. (2000) 44: 29-34

http://www.intjdevbiol.com/web/paper/10761843

Amphioxus Hox genes: insights into evolution and development

$\mathrm{J}$ Garcia-Fernàndez and $\mathrm{P}$ W Holland

Int. J. Dev. Biol. (1996) 40: S71-S72

http://www.intjdevbiol.com/web/paper/9087701

5 yr ISI Impact Factor $(2013)=2.879$

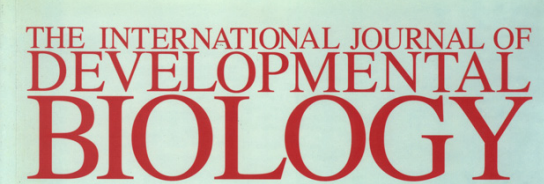

Volume 40 No. 4

August 1996

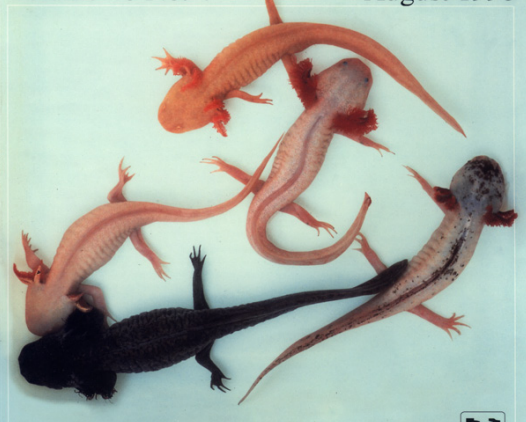

Developmental Biology of Urodeles
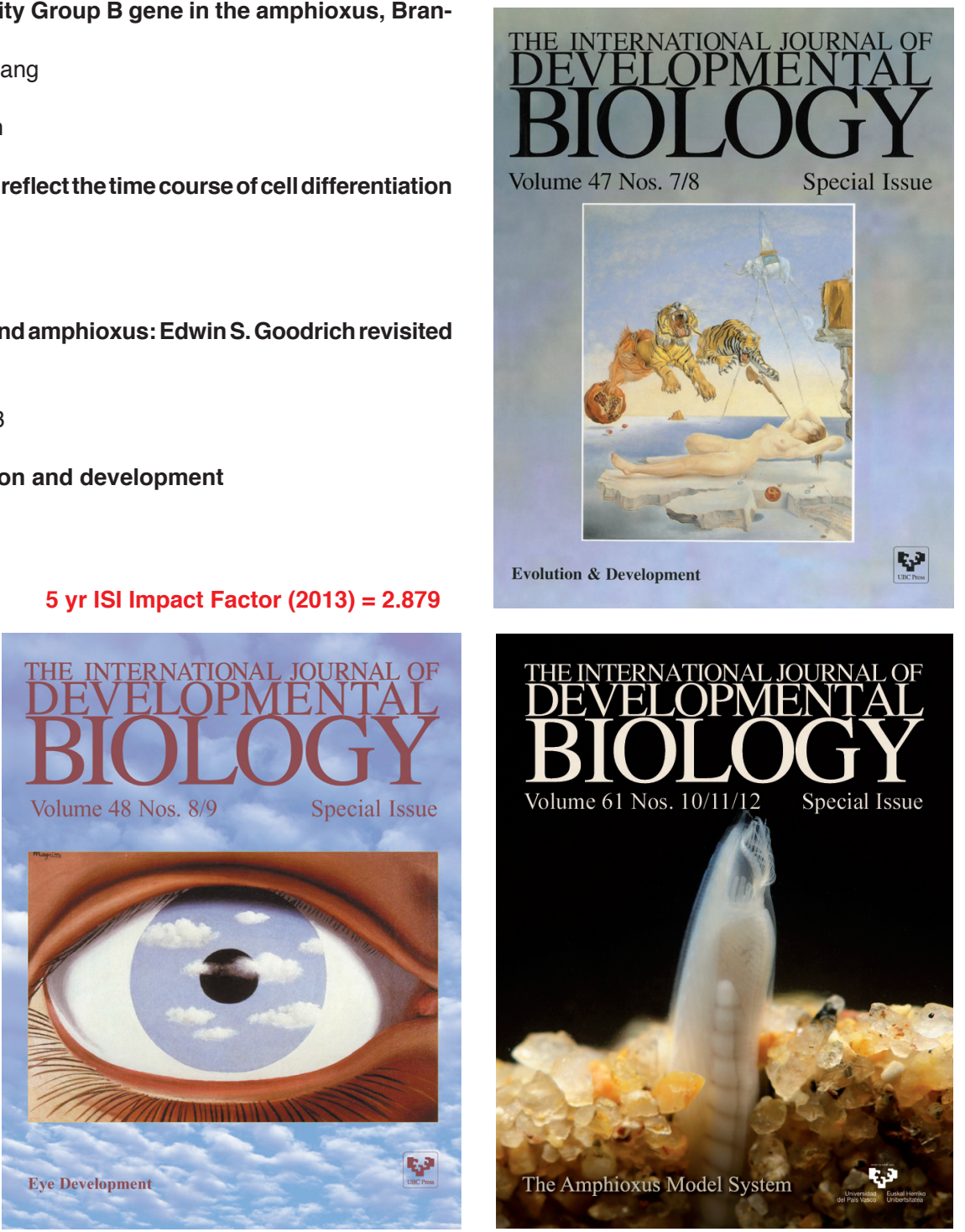